\title{
Republic of Serbia: Selected Issues
}

This Selected Issues paper for the Republic of Serbia was prepared by a staff team of the International Monetary Fund as background documentation for the periodic consultation with the member country. It is based on the information available at the time it was completed on August 16, 2006. The views expressed in this document are those of the staff team and do not necessarily reflect the views of the government of the Republic of Serbia or the Executive Board of the IMF.

The policy of publication of staff reports and other documents by the IMF allows for the deletion of market-sensitive information.

To assist the IMF in evaluating the publication policy, reader comments are invited and may be sent by e-mail to publicationpolicy@imf.org.

Copies of this report are available to the public from

International Monetary Fund $\bullet$ Publication Services

700 19th Street, N.W. • Washington, D.C. 20431

Telephone: (202) 6237430 • Telefax: (202) 6237201

E-mail: publications@imf.org • Internet: http://www.imf.org

Price: $\$ 18.00$ a copy

\section{International Monetary Fund Washington, D.C.}





\section{INTERNATIONAL MONETARY FUND}

\section{REPUBLIC OF SERBIA}

\section{Selected Issues}

Prepared by Tokhir Mirzoev, Eric Mottu, Andreas Westphal (all EUR); Peter Hayward (MFD Consultant), Anna Ivanova (FAD), Haimanot Teferra (AFR) and Janko Guzijan (Resident Representative Office)

Approved by the European Department

August 16, 2006

Contents

I. Overview and Summary 4

II. Gross Domestic Capital Formation and External Deficits.................................................6

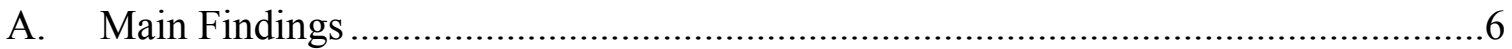

B. Domestic Investment and External Deficits in Transition.........................................7

C. Investment, Income per Capita, and Compositional Factors ......................................10

D. Current Account Deficits and External Debt Developments.....................................11

Figures

1a. Selected CEEC and SEE Countries: Gross Investment, Current Account Deficit and

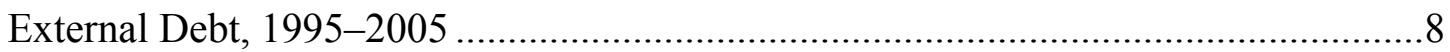

1b. Selected CEEC and SEE Countries: Gross Investment, Current Account Deficit and External Debt, 1995-2005 .................................................................................

2. Selected CEEC and SEE Countries: Current Account Deficit, FDI Inflows and External Debt, 1995-2005 …………………………….......................................13

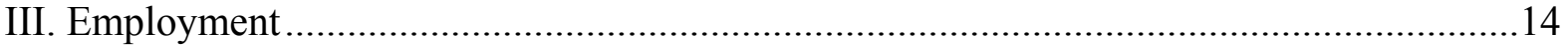

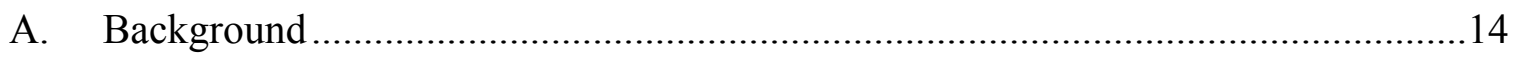

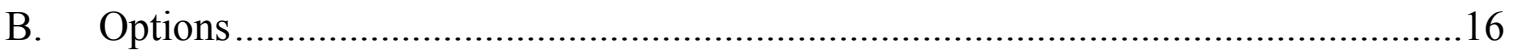

\section{Text Tables}

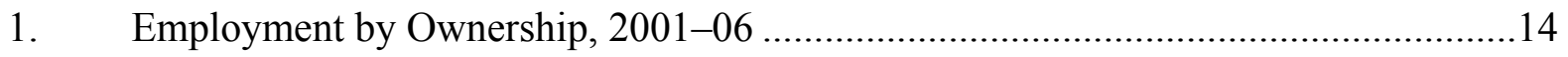

2. Labor Market Developments, Labor Force Survey Data.............................................15

3. Components of Unit Labor Cost in Manufacturing …………..................................15

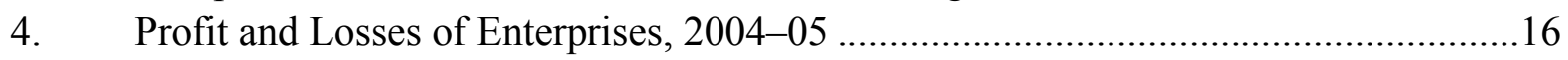


References

Tables

1. Employment by Ownership, 2001-06 ...............................................................21

2. Changes to the Personal Income Tax and Social Security Contributions...................22

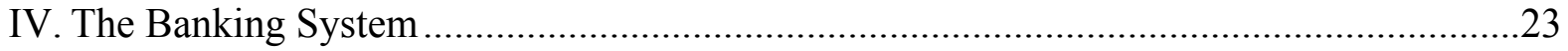

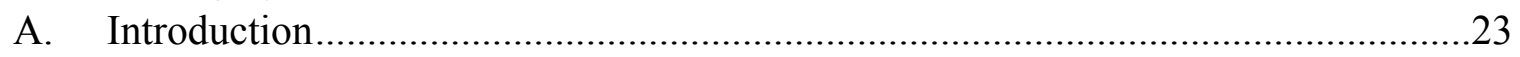

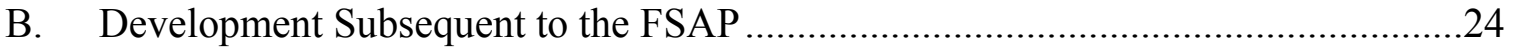

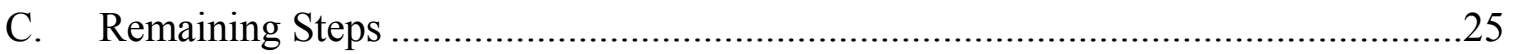

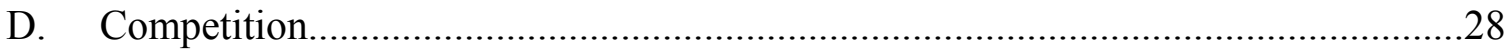

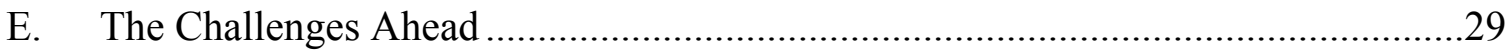

V. Economic Structure and Choice of Exchange Rate Regime.........................................32

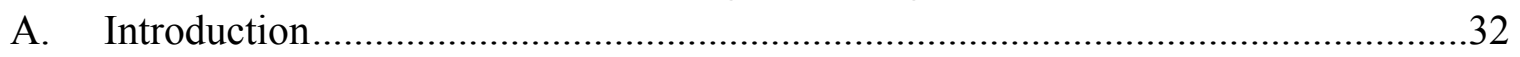

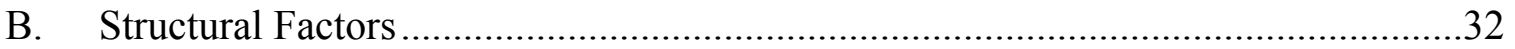

C. Serbia's Structural Characteristics in International Context ..................................33

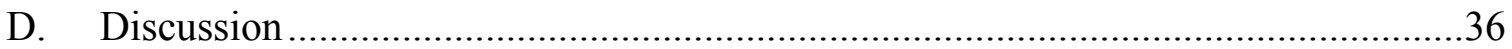

Tables

1. Quantitative Assessment of the Choice of the Exchange Rate Regime ..................34

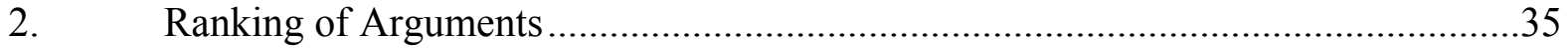

3. Exchange Rate Regime Considerations, 2005 ...............................................35

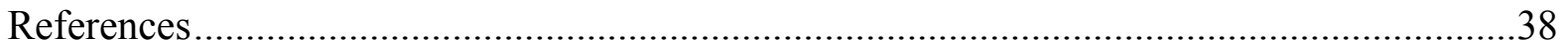

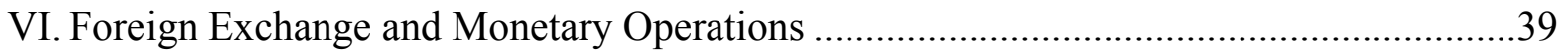

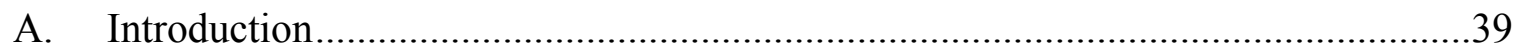

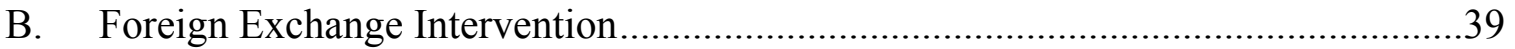

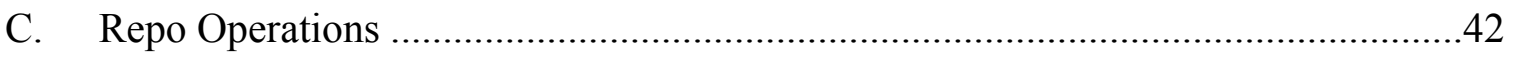

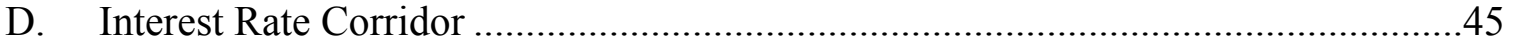

E. Transmission From the Repo Rate to the Exchange Rate ....................................47

Figures

1. Repo Rates and Belibor .......................................................................43

2. Beonia, Belibor, Repo Rates, and NBS Lending and Deposit Facilities ................46

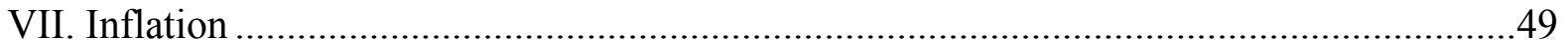

A. Exchange Rate Pass-Through to Core Inflation ....................................................49

B. Inflation Targeting: Emerging Market Experience .............................................55 


\section{Text Tables}

1. Core Price Index and Exchange Rate, Number of Cointegrating Relations ..............50

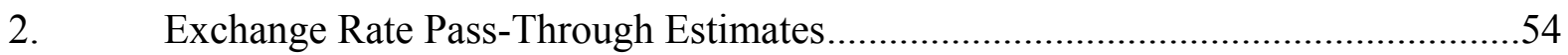

3. Inflation Prior to the Transition to Full-Fledged Inflation Targeting .......................57

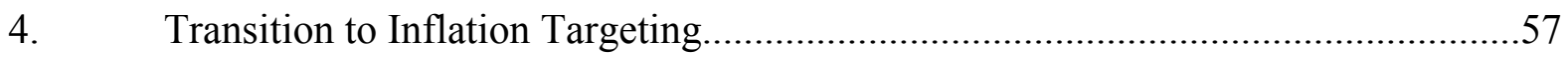

\section{Text Figures}

1. Nominal Exchange Rate and Retail Prices Twelve-month growth .........................50

2. Daily Exchange Rate Dinar/Euro, Feb 01, 2005 - July 21, 2006 …........................51

3. Exchange Rate and Core Price Index ………....................................................52

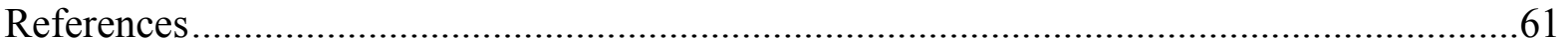

Appendix Table A.1: Composition of the Non-Core Price Index, 2006 ................................62 


\section{OVERVIEW AND SUMMARY}

1. Serbia has made significant economic progress since 2000. Output is up 40 percent and the share of the private sector in non-agricultural non-budget employment has almost doubled to around 60 percent. These advances have reversed the decline of the previous two decades. In light of this progress, these notes aim to shed light on the challenges ahead.

2. Chapter II considers gross domestic capital formation in a regional context. With capital formation rates regionally low and employment reportedly falling, much of the economic recovery since 2000 has reflected growth in total factor productivity. In part, this is the dividend of corporate reforms which have increased efficiency. But even with the exceptional steel investment in 2004, Serbia's investment ratios are well below those in other transition countries. Even allowing for data quality uncertainties, these investment patterns raise questions about the sustainability of Serbia's recent economic growth. The note infers that these investment patterns indicate that a significant further reform agenda — ranging from improved business and political climates, to bankruptcy and privatization - still lies ahead. Such an agenda would address the roots of low investment by both domestic and foreign investors. And evidence from the region that domestic non-government savings rates move in tandem with non-government investment points - as do other macroeconomic indicators in Serbia - to the need to prioritize increased corporate savings.

3. Chapter III focuses on employment. With the unemployment rate at 21 percent and rising, employment reportedly in trend decline, and future restructuring set to result in further layoffs, the issues are challenging. The note is exploratory, suggesting lines of enquiry rather than firm conclusions about the way ahead. It reports that the employment structure has shifted to the private sector, but cautions that data are not yet conclusive as to whether this is re-classification due to privatization or whether private firms are creating new jobs. It suggests that Serbia's labor institutions could be reassessed in view of the high and rising unemployment, including the complex wage setting mechanisms in the public sector inherited from the Yugoslav era. In that light, it queries the benefits of the 2005 Labor Law, which increased "insider" labor market rights and, noting particularly high unemployment among young people and females, recommends that the impact of labor market rules on these groups should form a particular focus for any review. It suggests that with corporate challenges still ahead, initiatives such as labor tax cuts, while helpful at the margin, cannot play a central role in improving employment performance.

4. Chapter IV turns to financial market issues. With rapid credit growth one of the consequences of earlier reform, notably of the banking system, the 2005 FSAP pointed to the need to strengthen banking regulation. Given that the 2005 banking law brought the legal regulatory framework largely in line with Basel Core Principles, this note emphasizes that the key challenge now is implementation. It notes that credit, which is largely fx-indexed lending to unhedged borrowers, requires strengthened regulatory capacity to monitor and manage indirect credit risk arising from foreign exchange exposures. 


\section{Drawing on these real and financial sector assessments, Chapter $V$ considers} issues in the choice of the exchange rate regime. Given the depth of the economic challenges inherited from the pre 2000 period, the monetary and exchange rate frameworks in Serbia since 2000 have had to strike difficult compromises between internal and external objectives. Partly to resolve these choices, the National Bank of Serbia (NBS) has begun taking steps towards eventual adoption of inflation targeting. The note observes that while several characteristics of the Serbian economy — most notably high euroization and high exchange rate pass-through - suggest the desirability of a relatively stable nominal exchange rate, others - notably the strength of capital inflows and associated risk of reversal - point towards the need for flexibility. In suggests that, on balance, increased flexibility in the exchange rate is appropriate. But the note goes on to posit that a flexible regime, managed with little or no discretionary foreign exchange intervention, but with other policies aimed to avoid excessive volatility in the nominal exchange rate, could provide the best fit for Serbia.

\section{Following on from this, Chapter VI points to the operational implications of} ambitions to increase exchange rate flexibility — anticipating inflation targeting. Given that greater exchange rate volatility necessitates a reformulation of foreign exchange intervention policies, the note suggests that operational distinctions should be drawn between various goals for intervention - such as maintenance of import cover, and "leaning against the wind" functions. It outlines how these purposes could be pursued while avoiding their misinterpretation by markets as official attempts to use intervention to determine the path for the exchange rate. It emphasizes, however, that this approach does not imply loss of official influence over the exchange rate path — but rather that the repo rate would become the main instrument for this and other monetary policy purposes. To this end, the note recommends a number of changes to repo operations, including focusing on the 14-day maturity and linking other NBS interest rates closely to the repo rate to establish a meaningful interest rate corridor. That said, the note cautions that even in the best of circumstances, the transition of the monetary and exchange rate regime will not be straightforward, underscoring the need, in particular, for full fiscal support to ensure its effectiveness.

7. Chapter VII discusses broader issues in the new monetary framework. It considers evidence for Serbia on the impact of the exchange rate on core inflation, observing that the great variety of parameter estimates for this relationship reflects both the short data sets and the multiplicity of structural shocks during even those short periods. While uncertainties remain, the evidence points to continued high pass through rates, perhaps particularly following exchange rate depreciations. Accordingly, the note considers lessons from other emerging market countries which adopted inflation targeting in the face of similar uncertainties about the determinants of inflation. It reviews how they set inflation goals, evolved their policy structures, and used "escape" clauses so as to balance need under inflation targeting for the authorities to provide inflation commitments with the technical constraints on their ability to achieve specific targets. 


\section{Gross Domestic Capital Formation and External Deficits ${ }^{1}$}

\section{This note compares patterns of domestic investment in Serbia for 2000-05 with those in other CEECs ${ }^{2}$ between 1995-2005, noting the relationships with external balances.}

\section{A. Main Findings}

\section{The main findings are as follows:}

- For the full CEEC region, higher fixed investment is generally associated with a higher current account deficits. In the absence of large FDI inflows, it is also associated with greater external debt accumulation.

- Similarly, for a given level of gross investment, an increase in public investment is associated with a widening of the current account deficit.

- And in the full region, a decline in private investment is usually associated with a decrease in FDI inflows and a decline in the current account deficit. In cases where private investment does not decline significantly in response to reduced FDI inflows, external debt increases.

- In Serbia, the large current account deficit has been associated with relatively low investment ratios compared to other CEECs (except Bulgaria) - although data doubts remain.

- Looking forward, the experience of other CEECs suggests that an increase in investment in Serbia may put pressure on the current account and external debt.

- Given Serbia's large external debt, financing its large investment needs will require achieving higher national savings and attracting larger non-debt creating flows.

\footnotetext{
${ }^{1}$ Prepared by Haimanot Teferra and Eric Mottu.

${ }^{2}$ In addition to Serbia, the Central and Eastern European Countries considered are Bulgaria, Croatia, the Czech Republic, Hungary, Poland, Romania, and the Slovak Republic.
} 


\section{B. Domestic Investment and External Deficits in Transition}

\section{High domestic investment, ceteris paribus, is associated with external}

imbalances. Thus, the investment needed for reconstruction and restructuring in the transition area might be expected to lead to temporary current account deficits, which would later correct as exports and growth pick up.

4. Several countries in the sample conform to this pattern (Figures 1a and 1b). This may be seen in Bulgaria 1998 onwards, in Croatia in 1997-99 and again in 2002-05, in the Czech Republic in 1995-97 and 1998-99, in Poland between 1995-2003, and in the Slovak Republic where the current account deficit matched developments in investment during the whole period.

5. In Serbia, the analysis of investment is hampered from the outset by the lack of a reliable data series. Specifically:

- National accounts data for gross fixed capital formation in 2000-03 probably underestimate private investment by about 5 percentage points of GDP, as suggested by preliminary official estimates for 2004 that take into account an improved coverage of the private sector, especially its investment in equipment. Thus, only the 2004 investment figure is meaningful.

- The decomposition of public and private investment is made difficult by the absence of data and by definitional specificities, i.e., the existence of socially owned enterprises. Investment decomposed between government and nongovernment was previously estimated by Fund staff to be roughly 14 and 86 percent of total, respectively, suggesting low "public" sector investment. However, recently published data estimate "public" sector (including socially owned enterprises) and private sector investment at 58 and 42 percent of total, respectively.

\section{With these caveats, Serbia's data suggests surprisingly high external deficits} given lackluster fixed investment ratios. Such delinks are not without precedent-after 2001, the Czech Republic and Hungary both reported continued high external deficits while fixed investment ratios declined, in both cases reflecting weakening domestic savings rates. But overall, Serbia's performance is unusual in degree - reporting large external deficits alongside low investment ratios. 
Figure 1a. Selected CEEC and SEE Countries: Gross Investment, Current Account Deficit and External Debt (In percent of GDP), 1995-2005
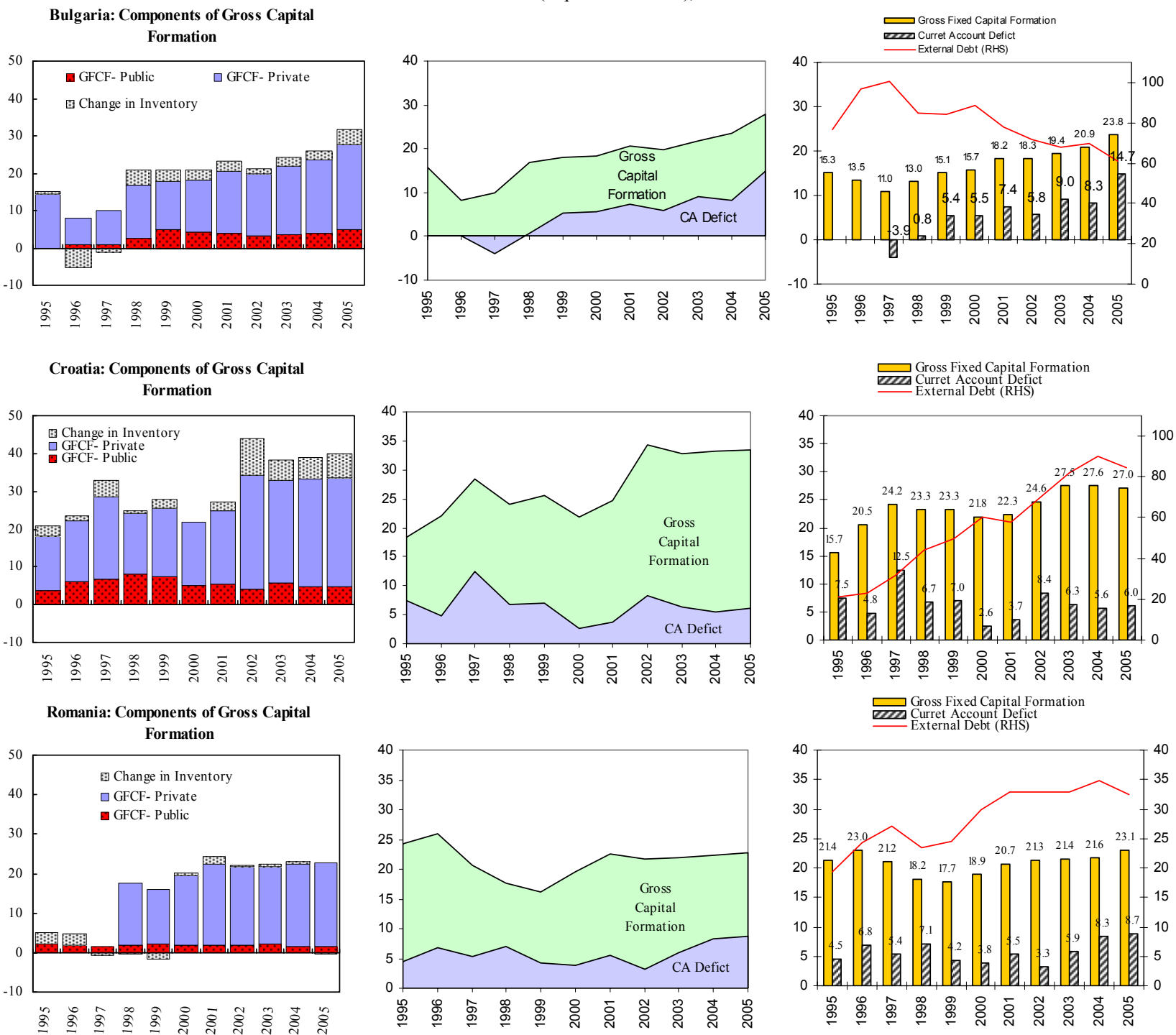

Gross Fixed Capital Formation

Curret Account Defict
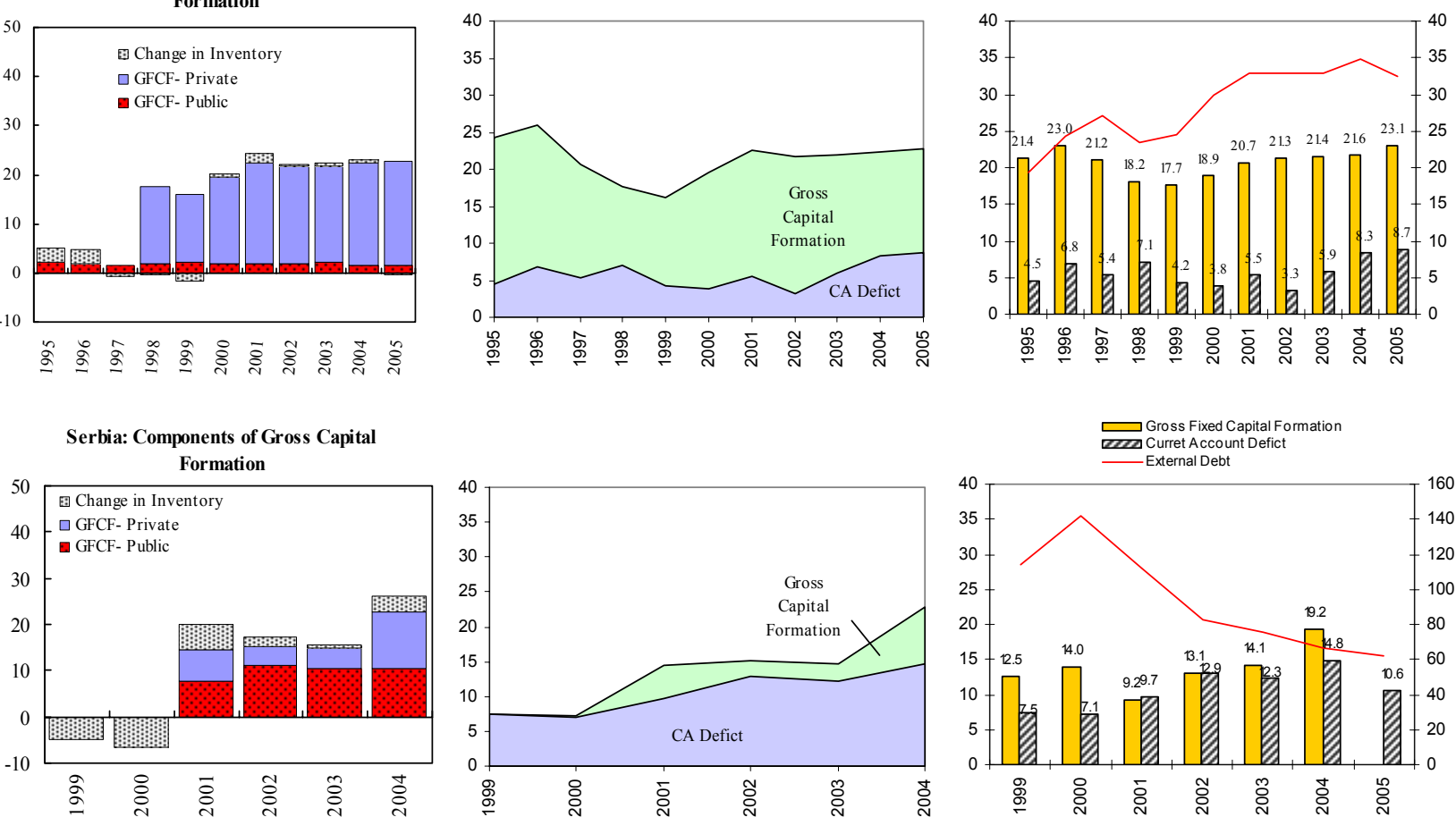

Sources: National Authorities and IMF staff estimates. 
Figure 1b. Selected CEEC and SEE Countries: Gross Investment, Current Account Deficit and External Debt (In percent of GDP), 1995-2005

Czech Rep.: Components of Gross Capital Formation

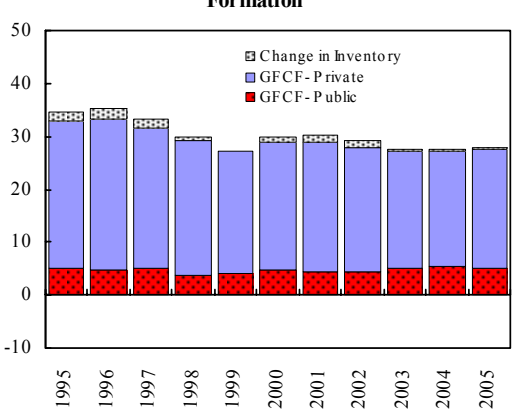

Hungary: Components of Gross Capital

Formation

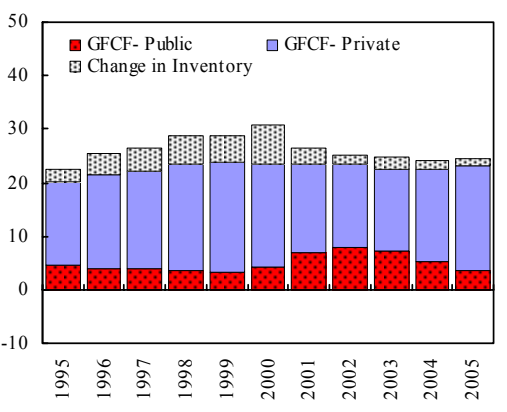

Poland: Components of Gross Capital

Formation

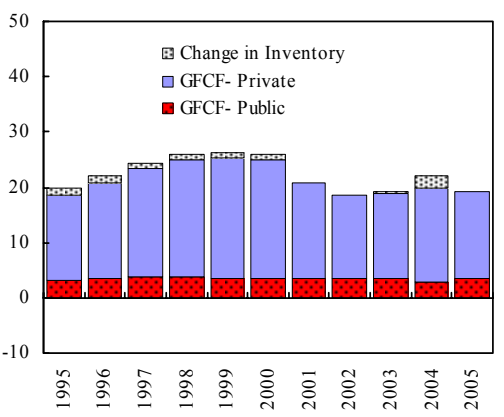

Slovak Rep.: Components of Gross Capital

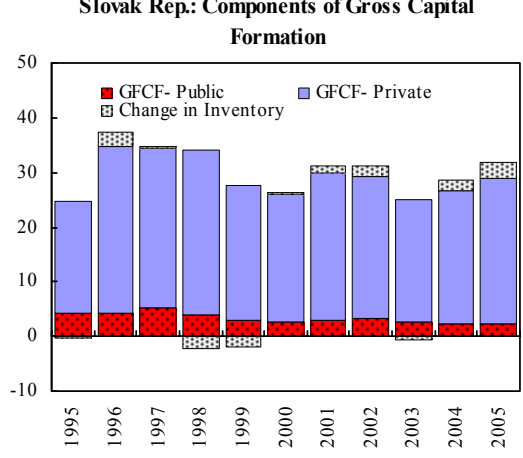

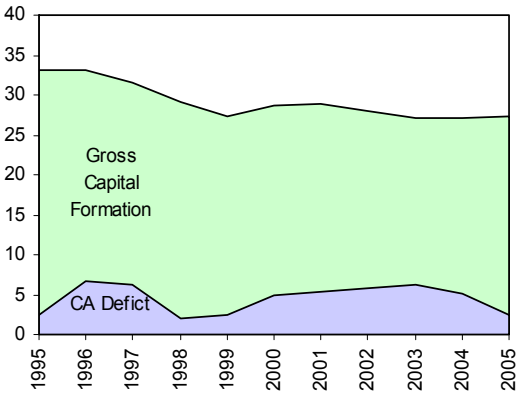
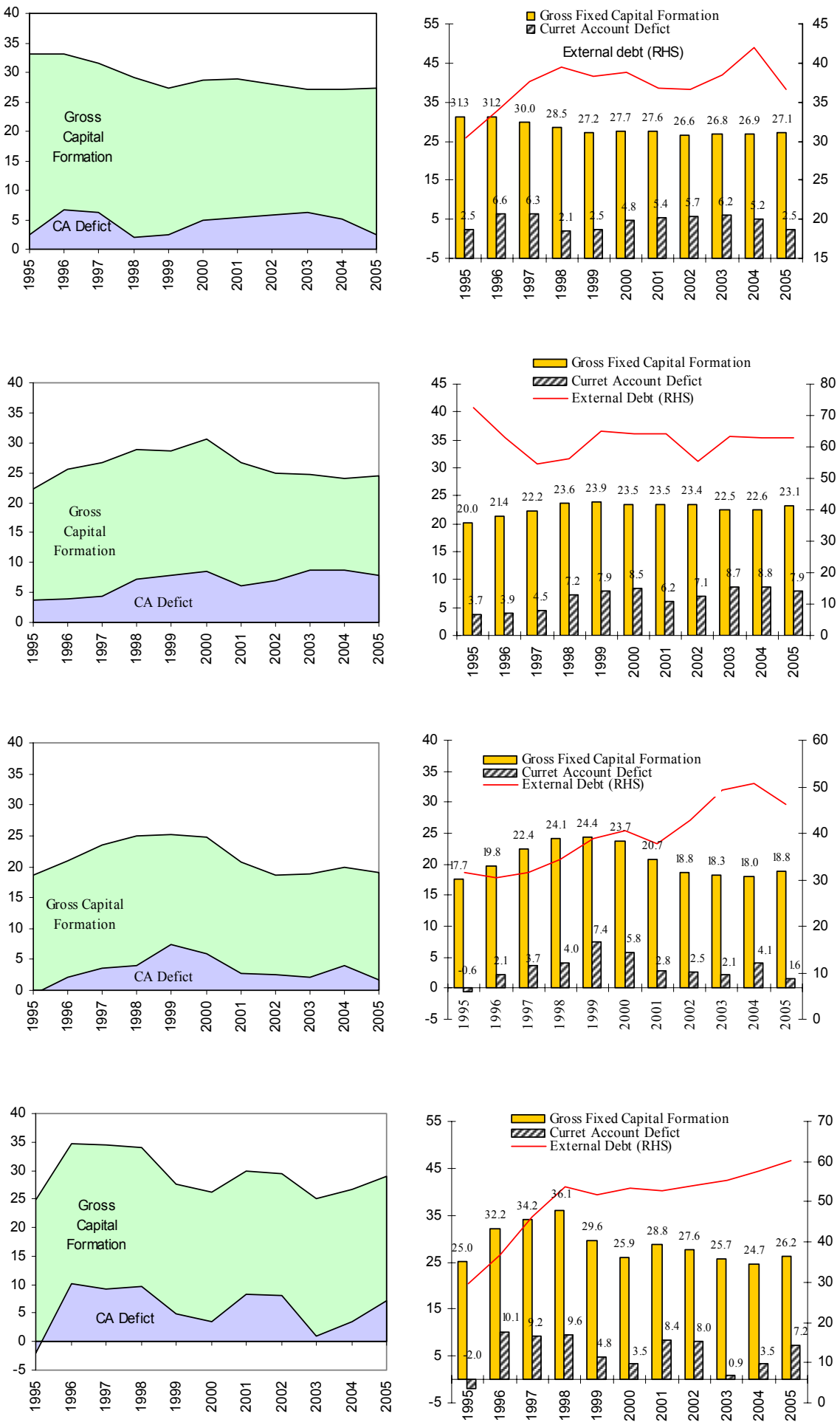

Sources: National Authorities and IMF staff estimates. 


\section{Investment, Income per Capita, and Compositional Factors}

7. A key feature in CEECs with relatively high GDP per worker (Croatia, Poland, Hungary, Czech Republic, and Slovak Republic) has been the relatively high level of fixed investment. In the Czech Republic, fixed investment was relatively high during 199597 at 31 percent of GDP, while in the Slovak Republic, it was even higher (32-36 percent of GDP) between 1996-98. In more recent years, fixed investment in these two countries stabilized at a lower, yet healthy level of 26-27 percent of GDP. On the other hand, in Poland, after continuously increasing through 1995-2000 to reach 24 percent of GDP, fixed investment dropped to stabilize at a lower level of 18-19 percent of GDP. In Hungary, fixed investment increased slightly from its 1995 level (20 percent of GDP) and has remained stable at around 23 percent of GDP since 1998. Fixed investment in Croatia started out at a relatively low level of 16 percent of GDP but reached a level comparable to the Czech Republic in 2003 (27 percent of GDP).

\section{The countries with the lowest GDP per worker-Serbia, Bulgaria, and} Romania-have fixed investment rates that, while increasing since 2001, remain comparatively modest. In Bulgaria, fixed investment only started to pick up in 2001, from an average of 15 percent in 1995-2000, increasing gradually to about 24 percent in 2005 . In Romania, fixed investment declined between 1996-99 from 23 to 18 percent of GDP, but the trend reversed in 2000, reaching 23 percent of GDP by 2005. Fixed investment in Serbia has been increasing since 2001, although it was still at a low level of 19 percent of GDP in 2004; however, data before 2004 are unreliable. This evidence suggests that, to some degree, low investment ratios in Serbia reflect the relatively low capital intensity of production (hence, low GDP per capita). But if GDP per capita is to rise in Serbia, then capital intensity and investment ratios will likely need to rise also.

9. The sectoral composition of investment is also unusual in Serbia. For the CEEC group, private fixed investment accounts for the bulk of total investment, while the public share accounts for less than 5 percent of GDP. Thus, since the start of the transition in Poland, Hungary, Czech Republic, and Slovak Republic, public investment has remained around 3-5 percent of GDP, was around 2 percent of GDP in Romania and Bulgaria. Only Croatia, where it is recorded at 6-7 percent of GDP, is relatively high. But even against Croatia's record, Serbia stands out with public investment_-including the large socially owned sector-relatively high at 10-11 percent of GDP. That said, Serbian general government investment is low at about 3 percent of GDP.

10. Serbia follows CEEC norms in the physical composition of investment. The ratio of construction relative to equipment investment is 3:2 in Czech Republic, Hungary, Poland, Romania, and Serbia, and 2:1 in Croatia. Nevertheless, low total investment in Serbia means that whereas in Croatia, the Czech Republic, Hungary, Poland, and the Slovak Republic, 
investment in construction is about 10-14 percent of GDP, in Serbia it is a low 7 percent of GDP.

\section{Current Account Deficits and External Debt Developments}

11. Although current account deficits often move in tandem with investment, external debt accumulation depends on the magnitude of non-debt creating flows, such as foreign direct investment (FDI). The two countries with the highest fixed investment, the Czech Republic and the Slovak Republic, financed the increase in investment quite differently. While both countries had a comparable level of fixed investment at the beginning of the transition period ( 30 and 33 percent of GDP respectively), in the Czech Republic, the current account deficit was about only 4.4 percent of GDP, indicating a high level of domestic saving, while in the Slovak Republic, it was on average 8.4 percent. External debt developments indicate that part of the current account deficit was financed through foreign borrowing in both countries. However, debt accumulation in the Slovak Republic was much higher (from 30 percent of GDP in 1995 to 52 percent of GDP in 1999) because of both its higher current account deficit and relatively low FDI inflows. In the meantime in the Czech Republic, external debt increased only from 30 percent in 1995 to 38 percent in 1999 due to higher FDI - including privatization - inflows. It is only in the later stages of transition (2000-03) that FDI inflows in the Slovak Republic exceeded current account deficits, even reaching 16 percent of GDP in 2002, more than twice the current account deficit. In the Czech Republic, FDI inflows continued to outpace current account deficits. As a result external debt seems to have stabilized at about 36 percent of GDP for the Czech Republic, while it is increasing continuously in the Slovak Republic.

\section{In Hungary and Poland, low FDI flows relative to external imbalances led to} significant external debt accumulation. In 1996-99, high fixed investment (around 23 percent of GDP) and large current account deficits were accompanied by external debt accumulation. In Poland, while the decline in fixed investment since 2001 reduced the current account deficit to about 2 percent of GDP, debt accumulation continued along with the decline in FDI inflows, requiring greater debt-financing. In Hungary, external debt declined between 1995-97 due to large FDI inflows, but increased again in 1998-99 when current account deficits almost doubled without a corresponding increase in FDI flows. Similarly, in 2002-03, a decline in FDI inflows without a reduction in current account deficits was associated with an increase in external debt. Patterns in Croatia and Serbia were similar, with FDI flows modest, certainly up to 2003, relative to external deficits. This put upward pressure on external debt ratios.

\section{Econometric analysis points further to the nature of links between domestic} capital formation and external debt. It suggests for the CEEC group that for a given level of gross investment, an increase in public investment is associated with a widening of the current account deficits whereas increases in private investment are not. A panel estimation (using a random effect GLS for unbalanced panel) was run with the current account deficit as 
the dependant variable and gross investment, public, and private investment as a percent of GDP as independent variables. We find that for a given level of gross investment, a percentage point increase in public investment as a share of GDP is associated with a 0.6 percentage point increase in the current account deficit as a percent of GDP. In contrast, we find no significant effect of a change in private investment on the current account balance. This points to the role of non-debt creating financing of private capital formationnotably internal financing by firms, and to the more debt intensive financing of publicincluding state-owned-investment.

14. Thus, Serbia is atypical in several ways. Overall investment rates are atypically low, even taking low income per capita into account, their composition is skewed towards public investment, with adverse consequences for the external deficit and debt, and relatively low rates of FDI financing compound these difficulties.

\section{Key implications for Serbia, given its large external deficit and high external} debt, are the need for higher investment and the requirement to finance it by raising national savings and non-debt creating flows. While Serbia's investment level in 2004 is comparable to the level of Croatia and Poland at the start of their transition, these countries had comparatively low external deficits and less than half of Serbia's external debt-to-GDP ratio. There, a strong base of domestic savings also meant that the widening of current account deficit, associated with the high investment that jumpstarted the transition, did not push external debt to unsustainable levels. In the case of Croatia, financing the external deficit through external borrowing was feasible, while in Poland, the relatively large FDI inflows helped to limit external debt accumulation. Increased domestic savings will thus likely be key to Serbia's investment, and hence its medium-term growth prospects. 
Figure 2. Selected CEEC and SEE countires: Current Acount Defict, FDI Inflows and External Debt (In percent of GDP), 1995-2005

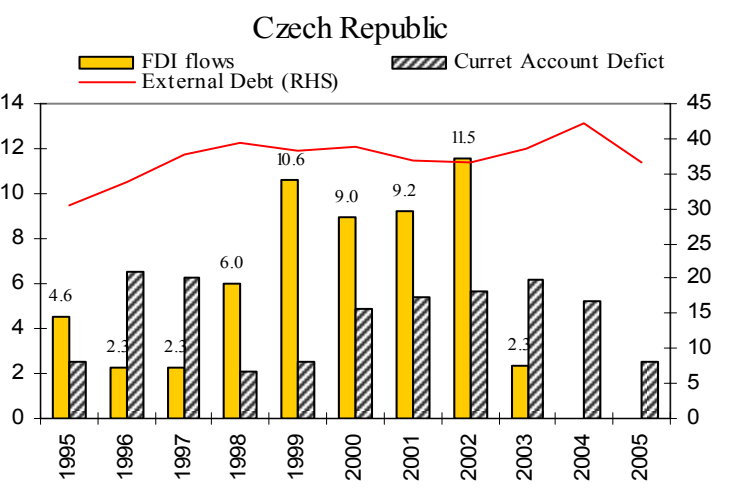

Hungary

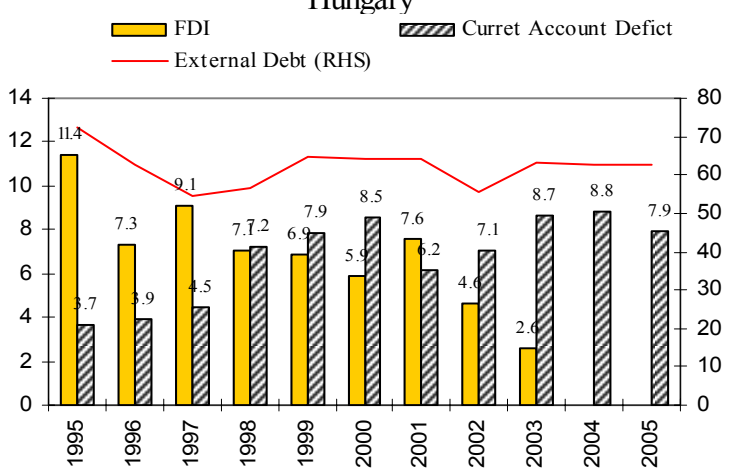

Poland

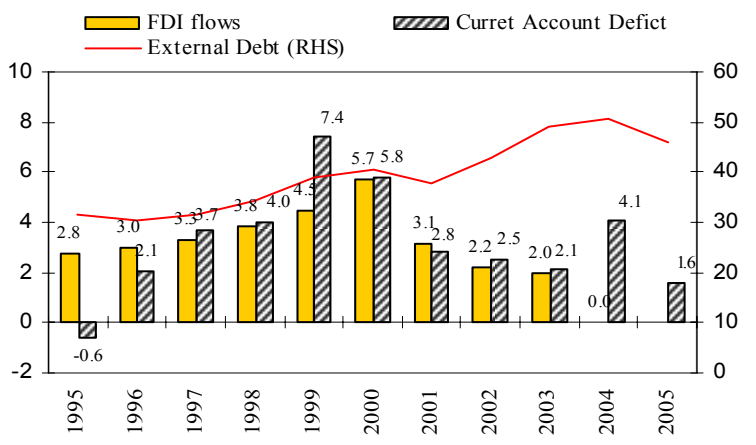

Slovak Republic

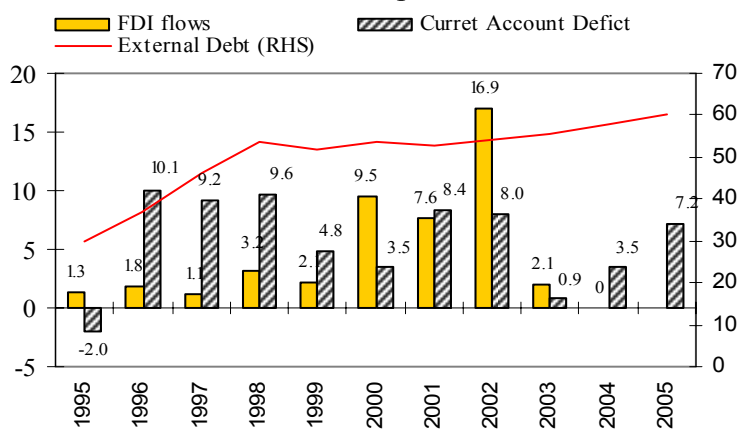

Bulgaria

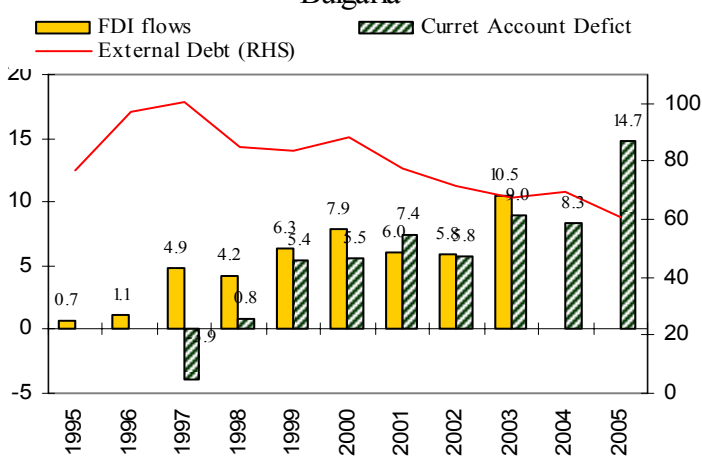

Croatia

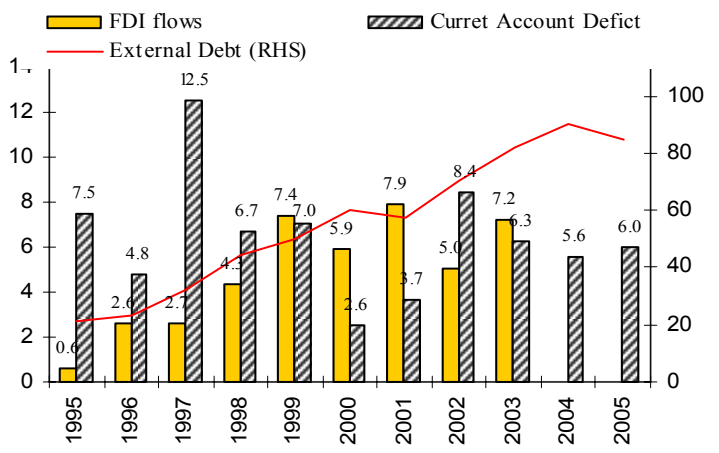

Romania
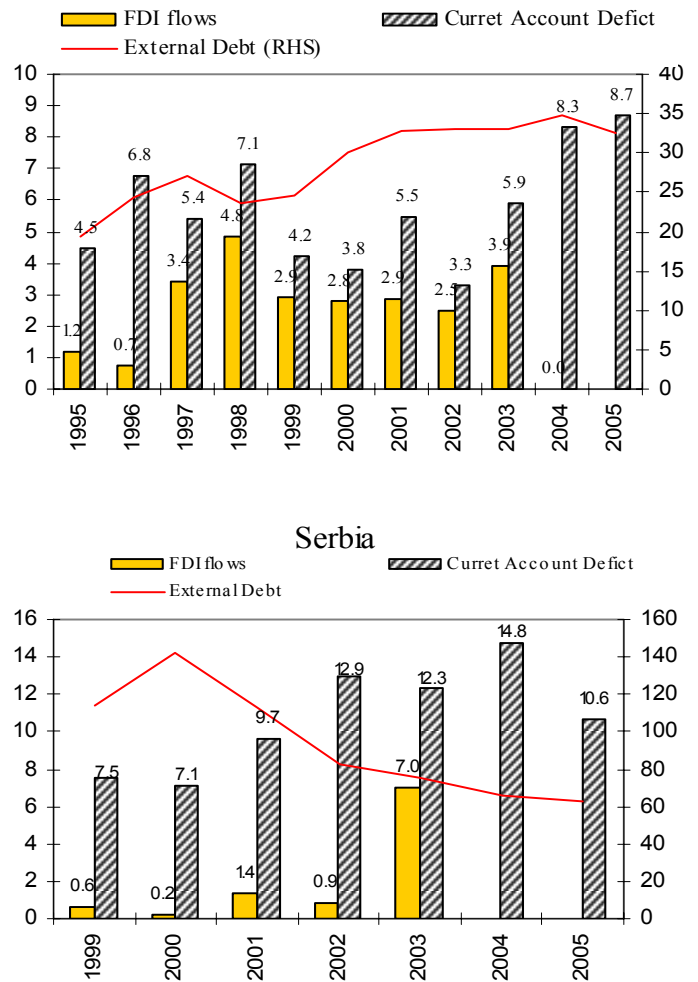

Sources: National Authorities and IMF staff estimates. 


\section{EMPLOYMENT ${ }^{3}$}

\section{This note considers how to improve employment performance in the medium-}

term. Its approach is exploratory, to identify possible areas for focus, and it anticipates further follow-up work by staff. Labor market institutions, corporate reform, and fiscal policies are discussed.

\section{A. Background}

\section{Almost 190,000 net jobs have been lost in five years, half of which were in} agriculture (Text Table 1 and Table 1). During this period, considerable reclassification of non-agricultural firms by sector occurred due to privatization. So while about 400,000 jobs were lost in the socially owned sector, 50,000 in companies with mixed ownership and 30,000 in national public enterprises, it is not clear precisely to what extent these were reclassified into the private sector due to privatization and improvements in data coverage.

Text Table 1. Serbia: Employment by Ownership, 2001-06

\begin{tabular}{|c|c|c|c|c|c|c|c|}
\hline & Sept. 2001 & Sept. 2002 & Sept. 2003 & Sept. 2004 & Sept. 2005 & Apr. 2006 & Diff. 06/01 \\
\hline & \multicolumn{7}{|c|}{ Number of persons } \\
\hline Total employment & $2,787,858$ & $2,736,087$ & $2,710,161$ & $2,678,509$ & $2,654,136$ & $2,600,776$ & $-187,082$ \\
\hline Non-private $1 /$ & $1,529,650$ & $1,418,750$ & $1,315,617$ & $1,231,843$ & $1,114,579$ & $1,050,151$ & $-479,499$ \\
\hline \multirow{3}{*}{$\begin{array}{l}\text { Private sector } \\
\text { Of which non-farm private sector }\end{array}$} & $1,258,208$ & $1,317,337$ & $1,394,544$ & $1,446,666$ & $1,539,557$ & $1,550,625$ & 292,417 \\
\hline & 566,479 & 629,502 & 720,673 & 804,946 & 952,849 & 963,917 & 397,438 \\
\hline & \multicolumn{7}{|c|}{ Sept. $2001=100$} \\
\hline Total employment & 100 & 98 & 97 & 96 & 95 & 93 & -7 \\
\hline Non-private $1 /$ & 100 & 93 & 86 & 81 & 73 & 69 & -31 \\
\hline Private sector & 100 & 105 & 111 & 115 & 122 & 123 & 23 \\
\hline Of which non-farm private sector & 100 & 111 & 127 & 142 & 168 & 170 & 70 \\
\hline
\end{tabular}

3. Furthermore, the employment rate is low. In 2005 the overall employment rate stood at 42 percent, well below the EU average of 67 percent. Employment rates for women (33 percent) and the workforce between 55 and 64 years old (35 percent) were also lagging behind EU levels (57 and 50 percent, respectively).

4. Unemployment rates are high and rising. According to the 2005 Labor Force Survey (LFS) the unemployment rate has reached 20.8 percent, up by over two percentage points from 2004 (Text Table 2), notwithstanding a slight decline in labor force participation.

\footnotetext{
${ }^{3}$ Prepared by Tokhir Mirzoev, Eric Mottu and Anna Ivanova, with contributions from Janko Guzijan.
} 
A majority of the unemployed (79 percent in 2005) has been without work for over twelve months and women and the young are affected most with the highest unemployment rates (27 and 48 percent respectively).

Text Table 2. Serbia: Labor Market Developments, Labor Force Survey Data 1/ (number of persons, unless indicated otherwise)

\begin{tabular}{|c|c|c|c|c|c|}
\hline & 2001 & 2002 & 2003 & 2004 & 2005 \\
\hline & \multicolumn{5}{|c|}{ Number of Persons } \\
\hline Labor Force (15 and older) & $3,538,275$ & $3,459,819$ & $3,418,914$ & $3,596,282$ & $3,453,293$ \\
\hline Employed & $3,105,598$ & $3,000,220$ & $2,918,589$ & $2,930,846$ & $2,733,412$ \\
\hline Of which in the private sector & $1,430,430$ & $1,417,126$ & $1,540,489$ & $1,667,767$ & $1,640,139$ \\
\hline Unemployed & 432,677 & 459,599 & 500,325 & 665,436 & 719,881 \\
\hline Unemployment rate, percent $2 /$ & 12.2 & 13.3 & 14.6 & 18.5 & 20.8 \\
\hline
\end{tabular}

1/ Source: Statistics Office and World Bank (2006). The survey methodology has been revised in 2004; hence the 2001-03 and 2004-05 numbers are not directly comparable.

2/ The ILO unemployment rate (for age group between 15 and 64) in 2004-05 was 19.5 and 21.8 respectively.

\section{Despite high unemployment, real wages have reportedly grown significantly}

since 2003. Official statistics suggest that real wages have risen by over 40 percent since 2003 (Text Table 3). But there are doubts about the quality of this data. They are based on

Text Table 3. Serbia: Components of Unit Labor Cost in Manufacturing, 2001=100

\begin{tabular}{lcccccc}
\hline & 2001 & 2002 & 2003 & 2004 & 2005 & $20061 /$ \\
\hline PPI & 100.0 & 110.7 & 117.2 & 128.4 & 145.1 & 159.1 \\
Production & 100.0 & 100.9 & 97.9 & 104.8 & 105.7 & 100.6 \\
Wages (net) & 100.0 & 150.0 & 175.9 & 215.7 & 272.9 & 310.5 \\
Employment & 100.0 & 91.7 & 85.1 & 78.2 & 73.8 & 70.4 \\
PPI/ULC & 100.0 & 81.1 & 76.6 & 79.8 & 76.1 & 73.2 \\
\hline
\end{tabular}

Source: Statistics Office and Fund Staff Estimates

1/ Through April

data from a monthly survey, which covers about 70 percent of registered employment, but excludes small business and is biased towards large companies in the public sector. ${ }^{4}$ The importance of these omissions, and the likelihood that they cause exaggeration of the growth of wages, is indicated by tax collections data which suggests that the average growth in the base of taxes on wages - the wage bill—since 2003 was in the range of 5 to 7 percent. Though, given declining employment, this is consistent with high wage rises, it is unlikely that the actual wage increases are as high as indicated by the labor force data. Further doubt

\footnotetext{
${ }^{4}$ See Stanić (2005) for a detailed discussion.
} 
is cast on the official wage data by evidence from labor force survey suggesting that in 2005 jobs in state- and socially owned enterprises on average paid, respectively, 24 and 12 percent more than in the private sector (World Bank (2006)).

6. Reported wage growth suggests compression of profits since 2000. Profit margins in manufacturing (as measured by the ratio of producer prices over unit labor costs, bottom row of Text Table 3) have declined by more than 4 percent over the last five years. And even if the adversity in these trends is exaggerated by faults in the wage data, other evidence suggests heavy loss-making. In 2005 the nonprivate corporate sector recorded a net loss of over 5 percent of GDP, a major drain on the economy (Text Table 4).

Text Table 4. Serbia: Profit and losses of enterprises, 2004-05 (In percent of GDP)

\begin{tabular}{|c|c|c|c|c|c|c|}
\hline & \multicolumn{2}{|c|}{$\begin{array}{c}\text { Profit-making } \\
\text { enterprises }\end{array}$} & \multicolumn{2}{|c|}{$\begin{array}{c}\text { Loss-making } \\
\text { enterprises }\end{array}$} & \multicolumn{2}{|c|}{ Net } \\
\hline & 2004 & 2005 & 2004 & 2005 & 2004 & 2005 \\
\hline Private & 4.9 & 8.1 & -2.4 & -4.8 & 2.5 & 3.2 \\
\hline Non-private & 3.5 & 3.1 & -10.6 & -8.4 & -7.1 & -5.3 \\
\hline State-owned & 0.7 & 1.7 & -2.4 & -2.5 & -1.6 & -0.8 \\
\hline Socially owned & 0.4 & 0.3 & -3.7 & -2.3 & -3.3 & -2.0 \\
\hline Mixed ownership & 2.3 & 1.0 & -4.5 & -3.4 & -2.2 & -2.4 \\
\hline Other & 0.1 & 0.1 & -0.1 & -0.2 & 0.0 & -0.1 \\
\hline Total & 8.5 & 11.1 & -13.0 & -13.2 & -4.6 & -2.1 \\
\hline
\end{tabular}

\section{B. Options}

\section{Labor market policies and institutions}

7. Many provisions of the 2005 Labor Law-while formally consistent with EU guidelines ${ }^{5}$ - reflect the desire to protect existing employment. This may discourage new job creation. The Law maintained the basic principles of its predecessor (2001 Labor Law), but featured higher severance payments, introduced retirement gratuity and experience pay, increased non-wage benefits (e.g., more reimbursable expenses, presents for employees' children), and contained more complicated layoff procedures. Annual leave regulations prescribing leaves of three consecutive weeks and a 12-month limit on fixed-term appointments without a possibility of renewal create further frictions. Many of these steps protect existing employment but discourage new hiring. Given that employment shortfalls predate the 2005 Labor Law, it cannot be said to account for them. But it could compound the difficulties.

8. Inefficiencies are further aggravated by non-market and non-performancebased wage setting in the public sector. At present, wages in the budget sector and public enterprises are defined by coefficient multiples of sector-specific base wages with precise

\footnotetext{
${ }^{5}$ EU guidelines (Council decision 2003/578/EC) emphasize job creation (guideline No. 2), but do not explicitly discuss prevention of job destruction in the context of structural reform.
} 
coefficients defined for each job title. Infrequent adjustment of these coefficients and their distance from market principles creates rigidities in the wage structure.

9. The structure of participation and employment rates is suggestive of need for particular analysis of the impact of labor market institutions on young people and women. European experience suggests that participation rates of women tend to increase along with economic growth. Given that female participation is now unusually low, a significant rise in the supply of female labor may occur in coming years. This would compound the already significant supply of young labor - much of which is already openly unemployed. Both factors suggest the need to give particular emphasis in labor market institution design to ensuring appropriate flexibility for these two cohorts of workers. One example is to consider the impact of the minimum wage structure on the young-who at present are covered by the same minimum wage levels as apply to more experienced and productive workers. In respect of female participation, inflexibilities in working arrangements may warrant review.

10. A further focus on redeployment services would be appropriate. The Labor Fund could be more active in identifying skills that are most needed in the private sector (e.g., through surveys) and providing adequate training. Targeted policies aimed at disadvantaged groups, notably women and the young, are also needed.

\section{Corporate sector reform}

11. Inefficient corporate structures hinder job creation. State and social ownership slow firms' expansion even when market conditions are propitious. And in other cases, including the oil sector, state and socially owned firms are expressly protected from open competition. The consequent inefficiencies constitute a tax on all other firms, impeding their expansion and job creation.

\section{Concerns in Serbia, however, focus on the job-destructive effects of}

privatization. Given the overstaffing in many state and socially owned firms and that the weakest of the state and socially owned firms remain to be privatized, these concerns are not without foundation. And the impact is likely to be felt most sharply on older workers. ${ }^{6}$ But there is nevertheless thus a balance to be struck between addressing the preservation of jobs in the state and socially owned sectors and the creation of new jobs which privatization would encourage, both in the sectors being privatized and in other sectors.

\footnotetext{
${ }^{6}$ For example, World Bank (2006) finds that in Pancevo over a quarter of displaced workers had job tenure of over 30 years and only 6 percent had less than ten years of experience.
} 


\section{The severety of loss making in the state- and socially-owned sectors indicates} that privatization cannot be delayed. The losses are draining domestic savings and account for much of the external current account deficit. Accordingly, attempts to preserve jobs in these sectors come at high cost in terms of employment elsewhere in the economy.

Furthermore, requirements for purchasers of such firms to maintain existing jobs may impede efforts to sell the firms. And as a number of these already have excess debts - which already stand in the way of swift sales - additional requirements on job preservation may not be feasible.

\section{Accordingly, efforts need to prioritize job creation given considerable direct job} loss likely from privatization and restructuring. Arrangements in a number of areas should be reviewed from this perspective:

- Labor law, as noted above.

- Wage and remuneration setting arrangements, especially in the public sector.

- Overall macroeconomic and business environment policies to ensure conditions propitious to new domestic and foreign private investment.

- Tax and social benefit policies pertaining to labor, as discussed below.

\section{Fiscal Measures}

\section{Appropriately designed temporary social assistance programs, possibly} including early retirement, may be considered. And in order to ensure affordability, costs of early retirement programs could be contained by providing lower pension compensation until beneficiaries reach full age-based eligibility.

16. Tax rates may also be adjusted. The government has recently adopted amendments to the personal income tax law and the law on mandatory social insurance contributions with the view to stimulate employment. Specifically, the proposal envisages a reduction of the personal income tax (PIT) on wages from 14 to 12 percent, introduction of personal allowance and two-to-three year exemptions from personal tax and the employer's portion of social security contributions for previously unemployed and new job market entrants under the age of 30 and over the age of 45 as well as the disabled (see Table 2).

\section{Reduction of the personal income tax rate on wages could facilitate employment.} Some empirical evidence suggests that in countries with imperfect competition and less flexible labor markets, lowering direct taxes on labor may help increase employment. In general, however, the role of tax policy in affecting employment is limited and fixing 
fundamentals at the core of the unemployment problem, such as labor market rigidities and impediments to private sector development play a greater role. ${ }^{7}$ The expected fiscal cost of lowering PIT on wages is high (over 1.4 percent of GDP) and should be compensated either by a reduction in current spending or an increase in broad-based indirect taxes, such as the VAT, or a combination of both to preserve macroeconomic stability.

18. However, the effectiveness of the proposed exemptions for the young and nearretirees appears to be unclear. While the measure could help bring the young into the formal sector ${ }^{8}$, thereby increasing the future tax base, empirical evidence suggests that benefits from targeted wage or social security tax reductions are limited due to the deadweight fiscal costs, substitution, and displacement costs. The deadweight loss occurs because some of the employment to be subsidized by exemptions would have occurred anyway. The substitution effect is the incentive to bias new hiring towards the subsidized groups but at the expense of workers who are not eligible for exemptions. Related to the substitution costs are displacement costs as firms that receive tax relief expand and displace employment in the firms that do not receive tax relief. Even though the legislation contains a provision requiring employers not to reduce the number of employees without exemptions as of September 1, 2006, the effect of exemptions on the overall employment may be minimal as substitution and displacement effects may dominate. Moreover, the floor on the number of employees that a firm has to maintain to qualify for an exemption presents an additional market rigidity. And it will not prevent employers from churning employment as they can replace workers who received exemptions after the specified two-three year period upon exemption expiration with the new beneficiaries. Finally, administering these exemptions could be a major burden.

\section{The 2006-2008 National Employment Action Plan, developed in cooperation} with the European Agency for Reconstruction (EAR), lays out the government's strategy in support of the ambitious goal of halving unemployment by 2010. Consistent with EU guidelines, the action plan rightly emphasizes job creation and entrepreneurship, promotion of adaptability and mobility in the labor market, developing human capital and increasing labor supply. The task ahead, given employment challenges, is to turn this into a sufficiently ambitious program of specific reforms.

\footnotetext{
${ }^{7}$ See, for example, Nickell (2004) and Zee (1996).

${ }^{8}$ World Bank (2006) finds that at present young workers mostly find jobs in the informal sector, which employed 43 percent of all workers in 2005.
} 


\section{References}

Nickell, S. 2004, "Work and Taxes," paper prepared for the conference: Tax Policy and Employment" organized by CESifo.

Stanić, K., 2005, "Registered Employment and Wages - Statistic Data and Trends 2000-05," in Quarterly Monitor (Belgrade: Center for Advanced Economic Studies).

World Bank, 2006, “Serbia: Labor Market Assessment,” (Washington: World Bank).

Zee, H., 1996, “Taxation and Unemployment,” Working Paper WP/96/45 (Washington: Iternational Monetary Fund). 
Table 1. Serbia: Employment by Ownership, 2001-06

\begin{tabular}{|c|c|c|c|c|c|c|c|}
\hline & Sept. 2001 & Sept. 2002 & Sept. 2003 & Sept. 2004 & Sept. 2005 & Apr. 2006 & Diff. 06/01 \\
\hline Total employment & $2,787,858$ & $2,736,087$ & $2,710,161$ & $2,678,509$ & $2,654,136$ & $2,600,776$ & $-187,082$ \\
\hline General government & 321,616 & 321,379 & 324,013 & 327,469 & 325,147 & 316,483 & $-5,133$ \\
\hline State-owned enterprises & 187,290 & 183,623 & 182,779 & 181,195 & 173,691 & 164,640 & $-22,650$ \\
\hline National & 134,938 & 130,317 & 127,284 & 123,992 & 112,303 & 104,250 & $-30,688$ \\
\hline Local & 52,352 & 53,306 & 55,495 & 57,203 & 61,388 & 60,390 & 8,038 \\
\hline Socially owned enterprises & 643,709 & 579,767 & 417,205 & 324,316 & 258,217 & 245,980 & $-397,729$ \\
\hline Mixed ownership & 377,035 & 333,981 & 391,620 & 398,863 & 357,524 & 323,048 & $-53,987$ \\
\hline Private sector & $1,258,208$ & $1,317,337$ & $1,394,544$ & $1,446,666$ & $1,539,557$ & $1,550,625$ & 292,417 \\
\hline Of which: Non-farmers & 566,479 & 629,502 & 720,673 & 804,946 & 952,849 & 963,917 & 397,438 \\
\hline Companies & 208,546 & 228,107 & 279,581 & 327,735 & 421,490 & 428,384 & 219,838 \\
\hline Entrepreneurs and their employees & 357,933 & 401,395 & 441,092 & 477,211 & 531,359 & 535,534 & 177,601 \\
\hline Farmers & 691,729 & 687,835 & 673,871 & 641,720 & 586,708 & 586,708 & $-105,021$ \\
\hline \multicolumn{8}{|l|}{ Memorandum items: } \\
\hline Non-agriculture non-gen. government & $1,774,513$ & $1,726,873$ & $1,712,277$ & $1,709,320$ & $1,742,281$ & $1,697,585$ & $-76,928$ \\
\hline State, socially, and mixed-owned enterprises & $1,208,034$ & $1,097,371$ & 991,604 & 904,374 & 789,432 & 733,668 & $-474,366$ \\
\hline \multicolumn{8}{|c|}{ (In percent of total) } \\
\hline Total employment & 100.0 & 100.0 & 100.0 & 100.0 & 100.0 & 100.0 & 0.0 \\
\hline General government & 11.5 & 11.7 & 12.0 & 12.2 & 12.3 & 12.2 & 0.6 \\
\hline State-owned enterprises & 6.7 & 6.7 & 6.7 & 6.8 & 6.5 & 6.3 & -0.4 \\
\hline National & 4.8 & 4.8 & 4.7 & 4.6 & 4.2 & 4.0 & -0.8 \\
\hline Local & 1.9 & 1.9 & 2.0 & 2.1 & 2.3 & 2.3 & 0.4 \\
\hline Socially owned enterprises & 23.1 & 21.2 & 15.4 & 12.1 & 9.7 & 9.5 & -13.6 \\
\hline Mixed ownership & 13.5 & 12.2 & 14.5 & 14.9 & 13.5 & 12.4 & -1.1 \\
\hline Private sector & 45.1 & 48.1 & 51.5 & 54.0 & 58.0 & 59.6 & 14.5 \\
\hline Of which: Non-farmers & 20.3 & 23.0 & 26.6 & 30.1 & 35.9 & 37.1 & 16.7 \\
\hline Companies & 7.5 & 8.3 & 10.3 & 12.2 & 15.9 & 16.5 & 9.0 \\
\hline Entrepreneurs and their employees & 12.8 & 14.7 & 16.3 & 17.8 & 20.0 & 20.6 & 7.8 \\
\hline Farmers & 24.8 & 25.1 & 24.9 & 24.0 & 22.1 & 22.6 & -2.3 \\
\hline \multicolumn{8}{|l|}{ Memorandum items: } \\
\hline Non-agriculture non-gen. government & 63.7 & 63.1 & 63.2 & 63.8 & 65.6 & 65.3 & 1.6 \\
\hline Private (non-farm) in non-agr. non-gen. gov. & 31.9 & 36.5 & 42.1 & 47.1 & 54.7 & 56.8 & 24.9 \\
\hline State, social, mixed in non-agr. non-gen. gov. & 68.1 & 63.5 & 57.9 & 52.9 & 45.3 & 43.2 & -24.9 \\
\hline
\end{tabular}

Source: Statistics Office. 


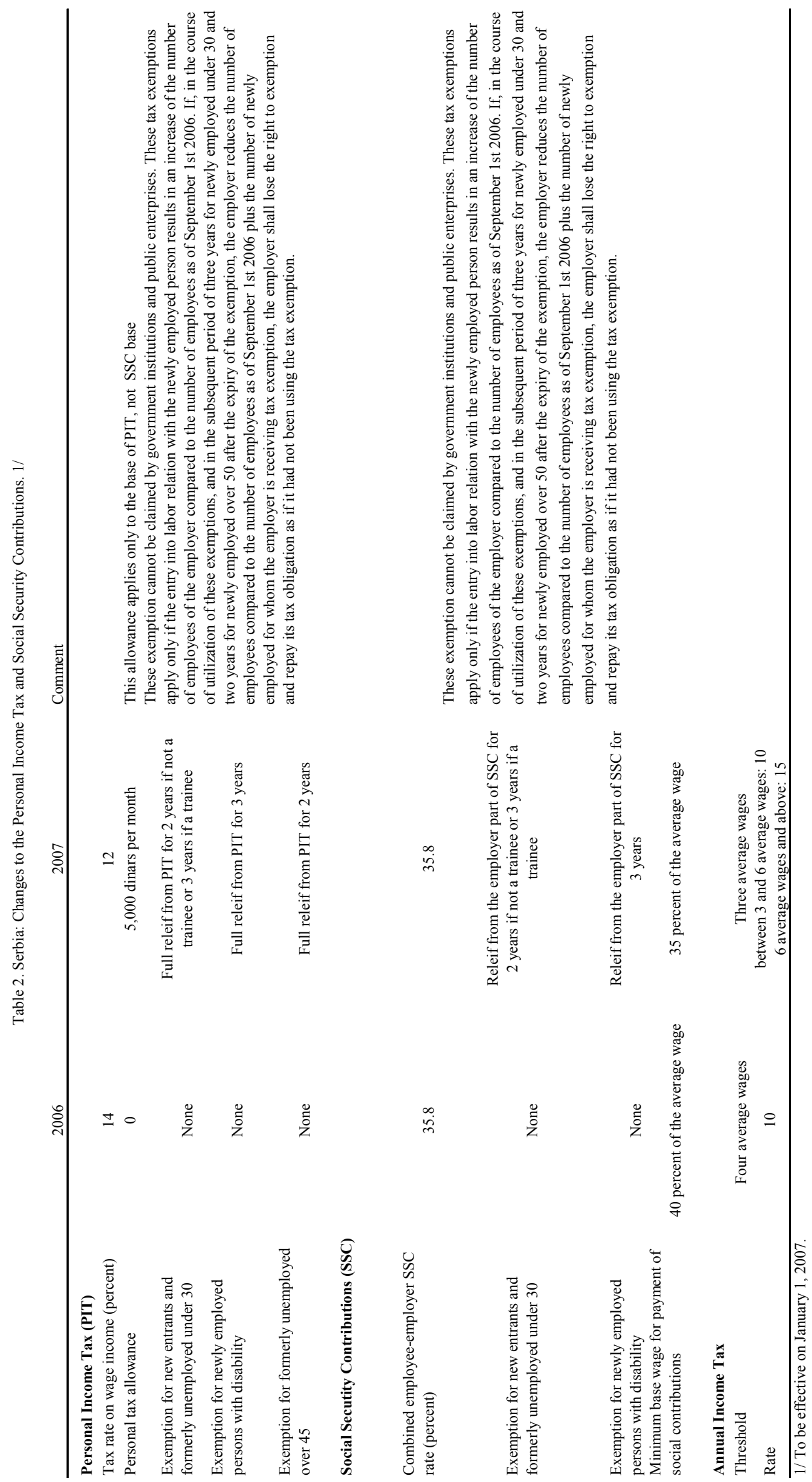




\section{THE BANKING SYSTEM ${ }^{9}$}

\section{A. Introduction}

1. This note examines recent developments in the Serbian banking system and the implementation of FSAP recommendations. ${ }^{10}$ It also discusses issues arising in the context of the transition to a flexible exchange rate regime and competition in the banking system.

2. The 2005 FSAP mission concluded that the rapid move from a limited statecontrolled to a dynamic market-driven financial sector has created important benefits, but also new policy challenges. The rapid credit expansion, largely fueled by foreign banks, whose share in total assets has risen to over 70 percent, is contributing to Serbia's long-term economic recovery. However, it has also complicated efforts to reduce inflation and the high current account deficit. In addition, the FSSA noted emerging signs that rapid credit growth had started to erode systemic financial stability by contributing to an increase in NPLs.

\section{The main potential threat to financial stability is high and rising indirect credit} risk. With 80 percent of all loans being either fx-indexed or fx-denominated, the exposure of unhedged borrowers to an unexpected depreciation of the currency is significant. Thus a decline in the profitability of foreign banks seeking to gain market share, coupled with an adverse shock - especially an unexpected depreciation - could ultimately result in a credit crunch with adverse implications for the economy at large.

\section{The FSSA also noted that these risks were exacerbated by weaknesses in} banking regulation and supervision. The Basel Core Principles assessment undertaken in April 2005 identified significant gaps in the banking law and regulations and found that weak enforcement has further reduced its effectiveness.

5. Rapid expansion of bank credit contrasts sharply with the nascent state of other financial market segments. In particular, the FSSA noted the lack of development of capital markets, the poor state of the insurance sector, weaknesses in bankruptcy legislation, and difficulties in taking and executing security. The transfer and pledging of real estate was

\footnotetext{
${ }^{9}$ Prepared by Peter Hayward and Andreas Westphal.

${ }^{10}$ The main findings of the Financial Sector Assessment Program (FSAP) team, whose two main missions to Belgrade were in March and April 2005, are reflected in the Financial System Stability Assessment (FSSA), which was discussed by the Fund's Executive Board on February 6, 2006. It is available at http://www.imf.org/external/pubs/ft/scr/2006/cr0696.pdf.
} 
difficult in the absence of an effective land registry. Finally, accounting and auditing practices are undeveloped and corporate governance is weak.

\section{B. Developments Subsequent to the FSAP}

6. Much has been achieved in the relatively short time since the FSAP was concluded and the legal framework of banking regulation and supervision now meets international standards. The new banking law that was adopted in November 2005 is largely in line with the Basel Core Principles (BCPs) and EU Directives. Deficiencies of the previous legislation underlay much of the noncompliance with the BCPs found in the FSAP. In particular, the new law provides for:

- Consolidated supervision of banking groups.

- Strengthened "fit and proper" requirements.

- Protection for the NBS and its staff in the execution of their duties.

- Limits on lending to parties connected to the bank, its directors and shareholders, in line with EU requirements.

- Improvements in corporate governance by making directors responsible for risk management and requiring banks to appoint audit committees.

- Obligation to publish financial statements compiled in accordance with International Financial Reporting Standards (IFRS).

7. The NBS has also adopted most of the by-laws that are necessary for the detailed implementation of the new banking law. All but two of these by-laws (NBS decisions) were issued before the legal deadline of 30 June, 2006. As the by-law on consolidated supervision will only take effect from end-2006, it was decided to use additional time for consultation. The by-law on competition in the banking sector is subject to further discussions on the institutional division of labor with the Competition Council. The by-laws provide for enhanced powers for the NBS to require banks to classify assets and provide for any diminution in value, taking account of the risks involved in fx-lending to unhedged domestic borrowers. Other relevant by-laws include implementation rules relating to licensing, capital adequacy, external audit, risk management, the conduct of supervision, including the enforcement of NBS recommendations, and 'know your customer' requirements. These decisions are in line with the law and international best practice, in particular EU requirements, and provide a sound basis for the implementation of the law.

8. The NBS has responded to the rapid expansion of credit risk involved in extending fx-denominated or fx-indexed loans to unhedged borrowers. From 
September 30, 2006, such loans in excess of CSD 10 million will receive a 125 percent weight in the capital adequacy calculation. Moreover, to contain lending to households, which grew by 96.2 percent in the twelve months to June 2006, the NBS has limited banks' exposure to households to 200 percent of capital, effective October 1, 2006. ${ }^{11}$ Moreover, the credit bureau, set up by the Association of Serbian Banks in 2004, is now fully functioning in respect of personal lending. It includes information about credit outstanding as well as default information. Coverage of business lending is expected by the end of 2006 .

\section{In addition, the NBS has stepped up its efforts to strengthen banking}

supervision. It has reorganized the supervision function - with World Bank assistance-so that the supervision strategy for each bank and its implementation, on-site and off-site, is the responsibility of a 'portfolio manager'. This has contributed to improvements in the supervision of asset quality and enforcement of compliance with minimum supervisory standards. Moreover, auditing and disclosure requirements have been improved and some progress has been made in dealing with breaches of statutory limits on connected lending.

10. Progress in bank privatization was substantial. Five banks were privatized since end-2004 and the privatization of another two banks - including Vojvodanska Banka, one of the two remaining systemically important state-controlled banks - is expected to be completed by end-2006, leading to a major diminution in systemic risk. Moreover, the EBRD has acquired a 25 percent interest in Komercijalna Banka, the other systemically important state-controlled bank, and appointed two members of the Managing Board, which is expected to improve governance and strengthen management. While the timing of the eventual privatization of Komercijalna Banka has not yet been determined, the government has expressed a clear preference for a public offer in the Serbian market.

\section{Remaining Steps}

11. The new legal framework needs to be swiftly implemented. The NBS is working on internal guidance to its staff on the implementation of its requirements set out in the law and the Decisions, in order to ensure consistency and effectiveness of their application. This process will inevitably take some time. It will also require some time for the banks to familiarize themselves with the provisions of the new law and changes in the supervisory processes. Moreover, the Decisions do not yet provide for capital requirements in respect of market risk. Now that the most important market risk, foreign exchange position risk, is

\footnotetext{
${ }^{11}$ Some categories of household loans are exempt from this provision, most notably mortgage loans subsidized from the budget.
} 
subject to a capital charge, the NBS regarded subjecting other forms of market risk to a capital charge as less urgent and has postponed proposals in this area.

12. The brisk pace of credit growth has led to increases in the already high share of nonperforming loans (NPLs) in total loans. While the overall NPL ratio has declined from 22.2 percent at end-2004 to 20.7 percent at end-March 2006, this decline reflects large writeoffs in state-controlled banks prior to their privatization. In contrast, the NPL ratio of foreign banks increased from 10.0 percent to 16.1 percent during the same period. ${ }^{12}$ However, the NBS noted - and major foreign banks concurred - that this increase reflects to a significant extent stepped-up enforcement of prudential provisions, in many cases involving the reclassification of loans whose quality may have deteriorated before 2005. In the same vein, foreign banks saw little evidence in their portfolio of a deterioration in the quality of underlying assets during 2005 and 2006 so far.

13. Looking forward, however, greater caution is warranted. Over the last few years, banks and their debtors benefited from high economic growth and the limited volatility in the exchange rate implied that unhedged borrowers were de facto shielded from effects of unexpected exchange rate changes. In addition, the credit cycle in Serbia is still at an early stage, given that the dramatic pick up in the pace of credit growth is only a relatively recent phenomenon. ${ }^{13}$ Against this background, and taking into consideration uncertainties with respect to the capacity of the banks' risk management systems to deal with their borrowers' exposure to exchange rate risk, asset quality may become an even larger concern in the not too distant future.

14. The transition from compliance- to risk-based supervision is in its early stages. Risk-based supervision requires staff who understand financial risks and can, therefore, initiate a dialogue with banks, both during on-site examinations and at other times, on the nature and extent of the risks that the bank exposes itself to, and the methods by which the bank prices, manages, mitigates, and controls those risks. The supervisors must be able to identify poor risk management and specify measures to correct these deficiencies.

\section{The NBS is considering the adequacy of its supervisory staff in light of the} transition to risk-based supervision. At present, the NBS relies on recruiting university graduates, mainly with economics or law qualifications, but almost always without much

\footnotetext{
${ }^{12}$ To eliminate the impact of changes in ownership, this calculation is based on an assumed constant ownership structure as of March 2006.

${ }^{13}$ The 12-month growth rate of credit to the nongovernment sector has exceeded 40 percent since August 2004 and 50 percent since January 2005.
} 
practical experience in commercial banking, accounting, or information technology. Salary levels in the NBS are low compared to market salaries for individuals with the skills needed which makes it difficult for the NBS to compete despite the job security. While this is a problem that almost all supervisory authorities face, it is particularly acute in Serbia. The decision to grant bonuses of 25 percent to supervision staff during on-site inspections was a first step in the right direction, but it may need to be complemented with a more flexible pay structure and other benefits that can reward scarce skills and strong performers.

16. Consideration could also be given to other transitory remedies. E.g., the NBS could hire experienced individuals at the end of their careers, who are interested to pass on their experience and knowledge to younger staff. Another common technique is to "outsource" part of the supervisor's activity to accounting and other specialist firms. Where the supervisor feels a bank does not have good quality systems it can require it to commission a consultant to undertake an investigation and to recommend remedial action. The firm would be hired and paid for by the bank, but the terms of reference would be for the supervisor to specify.

17. Risk-based supervision also requires changes in organization. In particular, these could comprise a flatter structure and improved horizontal as well as vertical communication. The appointment of portfolio managers responsible for the total supervisory effort in respect of each supervised institution was an essential step towards modern supervision where onsite examination is used to verify implementation of approved polices in a continuous iterative process. But again it requires highly skilled and experienced individuals to keep abreast of new developments in risk management, a necessary condition for providing effective supervision. This puts a high premium on training, both internally and externally.

\section{A major unresolved issue remains in relation to financial reporting, where NBS} requirements differ from IFRS. The difference is particularly pronounced in the valuation of assets. This has led some foreign banks to prepare and publish two sets of accounts. The first, in accordance with NBS classification and provisioning rules, which is also used by the tax authorities for the computation of corporate income taxes, and a second set, prepared in accordance with group accounting policies and audited as part of group financial statements. For 2005 the latter has resulted in lower provisions and thus higher profits. An associated issue is the fact that no progress has been made in establishing a national accounting and auditing standards body as provided in the recently passed law on accounting and auditing.

\section{Despite recent reforms, there remains some uncertainty for banks in using legal}

remedies. Considerable steps have been taken to enable banks to make more informed credit assessments, to take and enforce collateral, and to collect from troubled borrowers. The credit bureau now provides full information about potential individual borrowers with details of credit outstanding and payment performance. The system is at present being extended to corporate borrowers - although some large lenders have been reluctant to share proprietary information with potential competitors - and the Association of Serbian Banks expects the 
scheme to be implemented with full coverage. Improvements have also been made in land registries facilitating the taking of mortgages on both commercial and residential real estate. A separate pledge registry has also been set up enabling banks to take a lien over movable property. Legislative changes improving banks' ability to recover debts and improvements in bankruptcy legislation have also been enacted. However, many of these changes are very recent and it is too soon to say whether the rights of creditors have been sufficiently enhanced to provide the protection available to banks in other countries.

\section{Competition}

20. Banks are energetically establishing themselves in a small—if rapidly growingmarket. With 38 banks remaining, many with ambitions to increase their market penetration, competition for market share has become quite intense. Margins, especially for large corporate business, have been declining once account is taken of the recent increases in reserve requirements on fx-liabilities. Indeed any profit on relationships with major multinationals' Serbian affiliates may now derive from added services rather than the margin on lending. Competition for SME lending seems to have had less effect on margins, but such business requires significant costs in establishing branch networks and relationship managers. The boom in less price sensitive consumer lending can partially compensate for these developments. But to some extent, the credit bureau is reducing barriers-to-refinancingby-borrowers by enabling them to switch more easily to banks with which they do not have a prior credit relationship. And the advent of a similar service for corporates should also strengthen banking competition in that sector.

\section{But overall profitability has been sufficient to maintain the banks' appetite for} rapid credit expansion and their capital strength. Although 2005 was a good year, some foreign banks claim to have made a loss after credit costs, at least on Serbian accounting standards. Some of these costs, however, reflect NBS adjustments to provision levels and relate to a deterioration of asset quality in previous years rather than a deterioration during the year itself. In fact, major foreign banks claim to have detected little deterioration in asset quality so far. Indeed, they report higher profits on an IFRS basis. But, evidence of strengthening profitibility notwithstanding, at some point, exposure limits set by foreign parent banks could become a binding constraint on further expansion, particularly as in Serbia these exposures are not limited to the equity investment in their Serbian subsidiaries, but also include their funding of a large part of the lending book. Moreover, it can be expected that more of the smaller banks will find it difficult to maintain profitability, and if so their position will be eroded and their franchise will decline in value. Most observers expect, therefore, some further consolidation, which could also involve the withdrawal of one or more of the bigger players. 


\section{E. The Challenges Ahead}

22. The Serbian banking system faces additional challenges from high euroization. Reflecting recent experience with hyperinflation and high uncertainty with respect to future economic policies, virtually all deposits except transactions accounts are fx-denominated. Banks report that attempts to sell dinar-denominated term deposit products meet with very little interest and they have little incentive to push such products given the lack of demand for dinar-denominated financing apart from NBS repo operations. Indeed, about 80 percent of credit to the nongovernment sector is fx-denominated or fx-indexed, implying a high share of borrowers without a foreign currency cash flow.

\section{The NBS has used reserve requirements on fx-liabilities to drive a wedge} between funding costs and lending rates. This has led some banks to increase lending rates. At present, statutory required reserves are 40 percent for $\mathrm{fx}$-denominated deposits and banks' foreign borrowing with maturities over two years, and - since May 2006 - 60 percent for banks' foreign borrowing with maturities up to 2 years. Assuming a cost of funds of 5 percent and that banks are unwilling to shift to dinar-denominated deposits-with a reserve requirement of only 18 percent — and associated dinar-denominated lending, this implies a wedge of about 3.3 and 7.5 percentage points, respectively. While several banks claim that the increased reserve requirements have already started to constrain lending, the strength of credit growth suggests that expected profitability is generally still sufficient. This may partially reflect a restructuring in the banks' credit portfolio in favor of loans to households which — at least so far-have exhibited a low interest rate elasticity of credit demand.

\section{Looking forward, however, the use of reserve requirements to contain rapid} credit growth has clear limitations. The current reserve requirements may already be leading to disintermediation - as suggested by the strength of direct corporate borrowingand further increases can only accelerate that trend. Looking forward, shifting lending to less comprehensively regulated segments of the financial markets may pose risks to the maintenance of financial stability. Foreign banks can easily use their parents to book loans offshore, either by lending to the parent company of the Serbian company or by booking a loan to a purely domestic borrower elsewhere. The euro-indexation of the bulk of new lending renders this process even easier. Banks have also been using leasing companies as a way of avoiding the burden of reserve requirements, but the advantage of extending loans through leasing subsidiaries declined since their foreign borrowing recently became subject to a reserve requirement of 20 percent.

\section{At some stage, the moratorium on new "green field" bank licenses will need to} be raised. Now that bank privatization is drawing to a close and the new banking law is enacted, it is appropriate to consider a policy for new entrants. It is unlikely that many major international banks will want to enter what they may now perceive to be a crowded market. But one or two may wish to follow their corporate customers to Serbia. More likely would be applicants from banks in Eastern Europe or the former Soviet Union. Such applications will 
need to face a rigorous 'quality' standard, including strict application of the "fit and proper criteria provided in the new banking law.

\section{The gradual transition to a flexible exchange rate regime may exacerbate}

prudential risks. The limited exchange rate volatility through early 2006 created incentives for borrowers to underestimate exchange rate risk. In the same vein, banks have not fully internalized indirect credit risk. The gradual transition to a flexible exchange rate regime should help raise the awareness of these risks. However, given that the regime change has so far resulted in an appreciation of the dinar, it is uncertain whether the banks give sufficient priority to upgrading their risk management systems with a view to fully internalize indirect credit risk. The NBS will thus need to tighten its grip in supervising the banks' risk management systems. The introduction of a 125 percent risk weight for loans to unhedged borrowers in the capital adequacy calculation is in principle a step in the right direction. However, it will need to be complemented with an intensified assessment of banks' internal procedures.

\section{High reserve requirements help moderate liquidity risk. Liquidity risk is} enhanced by these reserve requirements given that the NBS cannot create liquidity in euro. It is, therefore, imperative that banks are required to ensure that they maintain access to foreign markets or at least limit their funding risk. At present, banks are subject to a stock liquidity requirement but there is no requirement limiting the extent to which banks indulge in maturity transformation. Although the NBS collects maturity information it is not disaggregated by currency so the supervisors would not necessarily be aware of mismatches. ${ }^{14}$ This could cause problems if there is a significant deterioration in asset quality and assets do not mature as soon as expected. The problem is not currently serious so long as the banks have to maintain large required reserves at the NBS, which can mitigate the lack of a 'lender of last resort' in euro. In the longer term, a flexible exchange rate regime should help the development of a foreign exchange market with more depth and breadth. In addition a forward market and a market for short dated swaps could help provide a term structure to the dinar money market and help the process of transmitting the NBS's repo rate to dinar interest rates. ${ }^{15}$

\section{Despite the impressive recent improvements in the legal framework, the Serbian} banking system remains vulnerable. The new regulatory framework needs to be swiftly

\footnotetext{
${ }^{14}$ Banks are, however, required to prepare liquidity management policies, dealing, inter alia, with liquidity on a currency by currency basis. These policies must include contingency plans.

${ }^{15}$ Currently the inter-bank market is small and mainly consists of overnight lending, and — as such lending is largely unsecured — not all banks with surplus liquidity are prepared to lend to all those who need funding.
} 
implemented to contain the risks emanating from rapid credit growth and the rising exposure of unhedged borrowers to exchange rate risk - even more so in the context of the transition to a flexible exchange rate regime. Given the limited history of default in recent years and the rapid growth of the customer base, deterioration may well creep up on lenders without much warning. Although margins have been relatively good and demand strong, competitive pressures are mounting. While many banks have earned respectable profits so far, the situation could change and further consolidation occur. The NBS now has adequate powers to deal with the problems that will no doubt arise but the supervisory capacity will need to be strengthened further to detect early warning signs. 


\section{ECONOMic Structure AND CHOICE OF EXChANGe RATE REgIMe ${ }^{16}$}

\section{A. Introduction}

1. This note considers the implications of the structure of Serbia's economy for its choice of exchange rate regime. The discussion is motivated by the authorities' intention to accommodate greater volatility in the exchange rate. It concludes that though a number of the characteristics of the Serbian economy point towards the desirability of a relatively stable nominal exchange rate, others point towards the need for flexibility. It therefore suggests that a flexible regime, managed with little or no discretionary foreign exchange intervention, but with other policies aimed to stabilize the nominal exchange rate to a significant degree could provide the best regime for Serbia.

\section{B. Structural Factors}

\section{Structural factors which influence the choice of exchange rate regime include:}

Openness: The more open a country, and the larger and synchronized its trade is with its main trading partner, the more it would gain from a stable (e.g., fixed) exchange rate with that partner.

Diversification: Diversified economies are less exposed to terms-of-trade shocks and can thus more easily live with a fixed exchange rate.

Capital flows: The more an economy is integrated into international capital markets, the greater its potential need for a flexible exchange rate to cushion against shocks to capital flows. This includes scope for residents to acquire foreign currency

denominated assets, either in the domestic banking system, or, if the exchange control regime allows, externally.

Shocks: If shocks are predominantly real, flexible exchange rates are more appropriate as they provide a useful adjustment mechanism. If shocks are predominantly nominal, a credible and stable fixed exchange rate regime may usefully reduce the incidence of such shocks. Countries with histories of high or hyperinflation may come into the latter category.

Dollarization: If high, this may reflect agents' judgment that inflation is more volatile than the real exchange rate, and is thus symptomatic of the high incidence of nominal

\footnotetext{
${ }^{16}$ Prepared by Eric Mottu.
} 
over real shocks. These characteristics, as noted above, tend to call for greater stability of the nominal exchange rate.

\section{Serbia's Structural Characteristics in International Context}

\section{Serbia's characteristics are compared with a large number of countries in}

Table 1. ${ }^{17}$ Countries are classified and ranked in regard to the structural criteria noted above amongst others, and Serbia's characteristics are reported alongside. Thus, on trade openness, the median for countries' shares of exports and imports in GDP is 55, while it is 66 for Serbia. This relatively high percentage for Serbia is reflected in the far right hand column as suggesting that Serbia should incline to more stability in its exchange rate. The same exercise is repeated for the other criteria.

\section{Drawing on Table 1, these indicators for Serbia are summarized on Table 2.} Though a number of indicators point towards flexibility, the scoring indicates that an unweighted examination of criteria tends to point towards the desirability of a stable exchange rate. This information is supplemented in Table 3 with more detailed data reported for Serbia. In summary, the high euroization, the high exchange rate pass-through, the long history of inflation, the high monetary volatility, and the limited financial intermediation place Serbia as a candidate for a stable exchange rate, relative to the other countries in the sample. Moreover, its relatively high trade openness, concentrated trade pattern (with respect to the euro area or countries pegged to the euro), synchronized cycle with trade partners, and the prevalence of monetary over real shocks also constitute factors in favor of stability. On the other hand, the presence of large capital flows argues in favor of flexibility, as well as the relatively high share of primary commodities exports and the high stock market turnover (which reflects large capital flows).

\footnotetext{
${ }^{17}$ See also Husain (2006). Whenever possible, we calculate the indicators for Serbia for a time frame as close as possible to that of the benchmark countries; we also report more recent figures for Serbia when those are significantly different from historical data.
} 


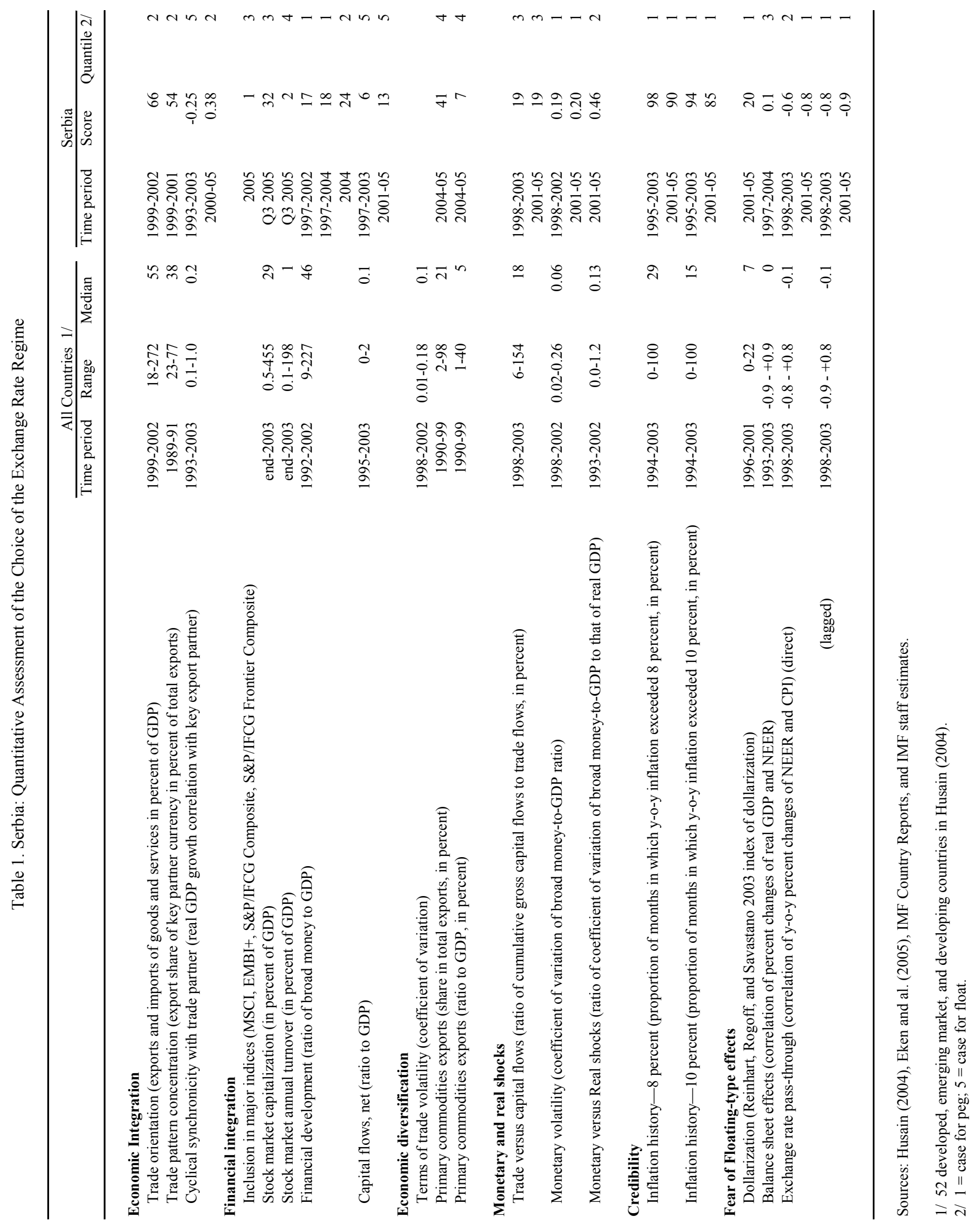


Table 2. Serbia: Ranking of Arguments

\begin{tabular}{|c|c|}
\hline Indicator & Quantile 1/ \\
\hline \multicolumn{2}{|l|}{ Case for a peg } \\
\hline High dollarization & 1 \\
\hline High exchange rate pass-through & 1 \\
\hline History of inflation & 1 \\
\hline High monetary volatility & 1 \\
\hline Limited financial development & 1 \\
\hline High trade orientation & 2 \\
\hline Concentrated trade pattern & 2 \\
\hline Synchronized cycle with major trade partners & 2 \\
\hline Prevalence of monetary shocks & 2 \\
\hline \multicolumn{2}{|l|}{ Case for a float } \\
\hline Large capital flows & 5 \\
\hline High share of primary commodities exports & 4 \\
\hline High stock market turnover & 4 \\
\hline \multicolumn{2}{|l|}{ No strong case } \\
\hline Average balance sheet effects on real activity & 3 \\
\hline Inclusion in only one major emerging market index & 3 \\
\hline Average trade versus capital flows & 3 \\
\hline Average stock market capitalization & 3 \\
\hline
\end{tabular}

Source: Author's calculations.

1/ Relative to 52 other countries in Husain (2004).

$1=$ case for peg; 5 = case for float.

Table 3. Serbia: Exchange Rate Regime Considerations, 2005 1/

\begin{tabular}{|c|c|c|}
\hline Indicator & Score & Units \\
\hline \multicolumn{3}{|l|}{ Case for a peg } \\
\hline High dollarization & 70 & Share of fx-deposits in total \\
\hline High exchange rate pass-through & 0.9 & On core inflation, one year \\
\hline History of inflation & 85 & $\begin{array}{l}\text { Percent of months with y-o-y inflation } \\
\text { higher than } 10 \text { percent in last } 5 \text { years }\end{array}$ \\
\hline High monetary volatility & 0.2 & Coefficient of variation of M2 to GDP \\
\hline Limited financial development & 27 & M2 to GDP \\
\hline High trade orientation & 76 & $\begin{array}{l}\text { Exports and imports of G\&S in percent } \\
\text { of GDP }\end{array}$ \\
\hline Concentrated trade pattern & 54 & $\begin{array}{l}\text { Export share to euro-linked partner } \\
\text { countries }\end{array}$ \\
\hline Synchronized cycle with major trade partners & 0.4 & $\begin{array}{l}\text { Real GDP growth correlation with euro } \\
\text { area }\end{array}$ \\
\hline Prevalence of monetary shocks & 0.5 & $\begin{array}{l}\text { Ratio of coefficient of variation of M2- } \\
\text { to-GDP to that of real GDP }\end{array}$ \\
\hline \multicolumn{3}{|l|}{ Case for a float } \\
\hline Large capital flows & 18 & Net capital flows to GDP \\
\hline High share of primary commodities exports & 41 & In percent of total exports \\
\hline High stock market turnover & 2 & In percent of GDP \\
\hline \multicolumn{3}{|l|}{ No strong case } \\
\hline Average balance sheet effects on real activity & 0.1 & $\begin{array}{l}\text { Correlation of real GDP and NEER } \\
\text { changes }\end{array}$ \\
\hline Inclusion in only one major emerging market index & EMBI+ & \\
\hline Average trade versus capital flows & 19 & $\begin{array}{l}\text { Cumulative gross capital flows to trade } \\
\text { flows, in percent }\end{array}$ \\
\hline Average stock market capitalization & 32 & In percent of GDP \\
\hline
\end{tabular}

Source: IMF staff estimates.

1/ Serbia was benchmarked against 52 other countries, as in Husain, 2004, mimeo, and Eken and al., 2005, IMF Country Report 05/419. Most figures refer to 2005, or to 2001-05. 


\section{Discussion}

5. Though useful, care is needed in interpretation of the results. For example, the evidence that Serbia exhibits monetary shocks is based on the volatility of velocity estimates compared to other countries. However, though velocity has changed significantly in Serbia since 2000, this is largely because of a sustained increase in depositor confidence in banks. Thus, though the change is reflected in this exercise as indicative of instability, the change in this case reflects a return to stability. However, the conclusion - that nominal shocks are high - may nevertheless be correct. In particular, an exercise like this requires somewhat arbitrary assumptions about the periods over which the indicators are measured. Here, the Serbian data reported are largely for the period since the late 1990s. But the most relevant period would be that which agents use to determine their own monetary behavior. That, of course, cannot be directly observed. But it may be inferred indirectly from Serbs' choices regarding financial euroization. The persistence of the latter in the face of sharp reductions in inflation since 2000 largely reflects lingering skepticism about inflationary prospects due to the two hyperinflations in recent memory. Thus, arguably, the data sets used for assessments of the sort in the exercise above should be longer because behavior by agents in respect of financial euroization indicates that in their view, monetary instability is high, regardless of the recovery of confidence in banks reflected in the velocity of broad money since 2000 .

\section{A further difficulty concerns the reliability of parameter estimates. While, as} noted above, the information contained in basic indicators reflects, in part, relatively arbitrary decisions about the time period over which the indicators are measured, parameter estimates - for factors such as pass through from exchange rates to inflation or the synchronization of activity with major trading partners - can be both period and methodology-specific. A variety of pass through estimates for Serbia are available and, as noted in Chapter 7, the variation in the estimates may reflect inadequacies with the techniques applied. With short data sets and multiple structural shocks both severely constraining the reliability of such parameter estimates, the implications for choice of exchange rate regime from estimates of behavioral parameters should be drawn with caution.

7. Structural change should also be taken into account. Basic indicators and parameter estimates, even when free of the concerns noted above, summarize information about the past. But structural change may be moving ahead rapidly, and in this context, the structural characteristics which will pertain - as opposed to those which pertained in the past - form the more pertinent basis on which to determine the choice of exchange rate regime. Of the various prospective structural changes, perhaps the key one for present purposes is increasing access to international financial markets. Access currently is limited by immediate political uncertainties and by the limited development of domestic financial markets. However, if those political difficulties are resolved, Serbia is likely to experience a rapid and significant deepening in its access to international capital markets. This factor 
would argue for progress towards greater flexibility in the exchange rate arrangements now so as to anticipate this development.

8. And the specific implications of structural characteristics-past or anticipatedfor choice of exchange rate regime are not always straightforward. For example, the suggestion in the literature that the high past or prospective incidence of monetary shocks points towards a fix is qualified to the extent that other mechanisms might be available to reduce the incidence of such shocks. For example, while a fix is one "technology" available to policymakers to reduce the incidence of monetary shocks, the adoption of a strong "inflation targeting" regime could be another such technology, even though it typically anticipates a float. This distinction may be important, as in the case of Serbia, where a number of considerations — such as openness to capital flows — argue against a fix.

\section{The exercise also requires some weighting of the various structural indicators.}

This issue is particularly acute when, as in the case of Serbia, the indicators point in different directions regarding the exchange rate regime. Given the large shocks to capital flows which emerging markets have experienced in recent years, echoed in market reassessments since Spring 2006, capital flows concerns should probably loom large in this relative weighting, pointing towards flexibility.

10. Finally, assessments such as those described may yield conclusions about the way in which a given exchange rate regime should be operated, as opposed to determining the choice of regime itself. Thus, as indicated above, Serbia's structural characteristics point in various directions regarding the choice of exchange rate regime, some pointing more to a fix, and others to a float. But if, for example, the arguments for a float are considered to dominate other concerns, the other structural characteristics could nevertheless also be reflected in policies which are aimed to minimize the volatility in the exchange rate under that regime. In other words, the structural characteristics said to point towards a fix in fact point towards stability, whether that is achieved through foreign intervention - a fix - or by other means under a float. Those other means could include the strength of supportive fiscal policy - including the swiftness and high quality of its response to macroeconomic shocks - and policy towards the central monetary policy interest rate (See Chapter 6).

11. A float supported by fiscal and monetary policies targeting stability, may be the best fit for Serbia. With capital flows issues and political uncertainties looming large, the case for a float is strong. High euroization, openness, and other structural factors calling for stability should, however, be reflected in the way the regime is operated. In particular, strong and appropriately flexible supportive policies - abjuring discretionary interventionalongside development of derivative markets to facilitate exchange risk hedging could aim to provide agents with a degree of stability in the external exchange rate appropriate to Serbia's structural characteristics. 


\section{References}

Eken, Sena, Abdourahmane Sarr, Jacques Bouhga-Hagbe, and Jérôme Vandenbussche, 2005, "Morocco: Exchange Rate Regime," in Morocco-Selected Issues, IMF Country Report No. 05/419 (Washington: International Monetary Fund), pp. 41-89.

Husain, Aasim M., 2004, "To Peg or Not to Peg-A Template for Assessing the Nobler," (Washington: International Monetary Fund), unpublished.

Husain, Aasim M., 2006, "To Peg or Not to Peg-A Template for Assessing the Nobler," IMF Working Paper WP/06/54 (Washington: International Monetary Fund). 


\section{FOREIGN EXCHANGE AND MONETARY OPERATIONS ${ }^{18}$}

\section{A. Introduction}

1. This note discusses the operational framework of monetary policy in light of the envisaged gradual transition to a flexible exchange rate regime and inflation targeting. It suggests the need to adjust foreign exchange intervention policies, improve the signaling function of 2-week repo operations, and strengthen the pass-through from the repo rate to other short-term interest rates.

\section{B. Foreign Exchange Intervention}

2. Since 2000, foreign exchange intervention has played a significant role in moderating volatility in the exchange rate. Thus, the announced intention of the National Bank of Serbia (NBS) to accommodate increased volatility should be reflected in amended fx-intervention policies.

3. Four issues arise: determination and realization of long run foreign exchange reserve targets; policy regarding daily volatility in the dinar market; determination of any remaining role of fx-intervention in guiding exchange rate trends; and institutional reforms in the fx-market. These are taken in turn.

\section{Reserve Accumulation Targets}

4. The NBS will need to hold an adequate stock of international reserves. The optimal level of foreign reserves may reflect need for a buffer against external shocks with the opportunity costs of holding reserves being weighed against the probability and size of such shocks. The target level chosen may also reflect the role of foreign reserves in forestalling currency crises, including under conditions of a floating exchange rate regime.

5. Furthermore, the NBS will need to decide whether to set reserve targets in gross terms or net of commercial banks' claims on the central bank. The former would be more appropriate if, in the event of a loss of confidence in the currency, depositor confidence in the domestic banking system is expected to be maintained. In that event, the full stock of gross reserves will be available to defend the currency should the authorities decide to do so. On the other hand, if a crisis is expected to be accompanied by a loss of confidence in banks in Serbia, a reserve target net of commercial banks' claims would be more appropriate. This is because with the loss of confidence in banks, commercial bank deposits with the central

\footnotetext{
${ }^{18}$ Prepared by Andreas Westphal.
} 
bank - and the associated international reserves - would decline. Thus, in this case, the full stock of gross reserves would not be available to defend the currency.

6. The targets set would change over time. Most basically, they could move in line with imports to maintain an overall import coverage. And there may also be occasion to set targets taking into account particular contingencies-for example, ahead of Kosovo-related uncertainties.

7. To realize these targets, the central bank will need to intervene in forex markets. This process needs to be consistent with market determination of the exchange rate. In particular, such interventions should be conducted so as to minimize risk that they are misperceived by markets as reflecting action to achieve an exchange rate target.

\section{To this end, the general policy—of interventions to meet "long-term" reserve} targets - should be announced and purchases made over time. To avoid risk of misperception of the transactions, the NBS could follow the example of some central banks which preannounced a schedule for their foreign exchange purchase auctions. The transparency in this approach helps underpin market understanding of the authorities' purposes, thereby maintaining market confidence in the authorities' commitment to a flexible exchange rate regime.

\section{Looking further ahead, structural reforms in the forex market could be} considered. In particular, the NBS may want to consider eventually encouraging establishment of a broker/dealer system in the foreign exchange market to replace the current fixing sessions. Amongst other benefits, this would help to focus market attention on the regularly published reserves data, rather than on individual central bank transactions in the forex market.

\section{Daily Dinar Volatility}

10. Exchange rate volatility may be excessive in a generally thin $\mathbf{f x}$-market. The NBS has the option, in this context, to allow the volatility itself to entice additional private agents into the market, thereby deepening it. Or, if that process is deemed likely to be too slow or to accommodate excessive daily volatility until it is complete, the NBS could provide the necessary smoothing by adopting a "leaning against the wind" approach to daily foreign exchange intervention to smooth daily changes.

11. If a "leaning against the wind" approach is desired, operational aspects will need to be considered. For example, the NBS could decide to intervene if the daily appreciation or depreciation exceeds a certain percentage threshold. This would help to smooth daily shocks. But, consistent with the commitment to accommodate greater exchange rate flexibility, cumulative daily appreciation or depreciation — even if sizeable — should not be resisted by foreign exchange intervention. While there may not be a need to announce the 
specific operational rule to execute these principles, the adopted rule should be applied consistently. This approach balances the credibility of the new regime-making clear that foreign exchange interventions are not guiding trends in the exchange rate-with the possible need for some flexibility in the specific policy rule used to "lean against the wind."

\section{Restructuring the Foreign Exchange Market}

\section{The NBS has purchased foreign exchange from the exchange offices at}

preferential rates. These flows largely reflect remittances and, conversion of eurodenominated "mattress money" into dinars in retail exchange offices. Given the preferential rate, the exchange offices have had no incentive to sell their receipts to commercial banks. These activities by the NBS have represented significant intervention, given that the NBS has not resold such purchases in the daily fixing sessions. Thus, these NBS purchases have been reflected in foreign reserve accumulation.

13. The NBS has reduced the preferential rates. The so-called "stimulation rate" was lowered from 1 percent to 0.9 percent on April 1 and to 0.7 percent on June 1. This marks an exit process for the NBS from these activities.

\section{Looking ahead, the NBS could announce a schedule for complete elimination of} the preferential rate. The process of exit should weigh two concerns: on the one hand, immediate withdrawal, while clean, might shock the foreign exchange market unduly; while, on the other hand, a general commitment to withdraw might qualify market confidence in the authorities' commitment to terminate discretionary foreign exchange intervention. Accordingly, announcement of a schedule for elimination balances these concerns. This would signal to market participants that the NBS is firmly committed to abjuring discretionary foreign exchange intervention, while avoiding the shock of immediate withdrawal. A binding monthly schedule to reduce the stimulation rate to zero, say over a six month horizon would best be accompanied by close consultations with the banks to facilitate their preparations to take over the business of the exchange offices.

\section{In the interim, the NBS should aim at reselling the foreign exchange acquired} from the exchange offices. The envisaged gradual further reduction in the stimulation rate should help reduce the amounts purchased by the NBS from the exchange offices. But to minimize the impact of the remaining purchases on reserve accumulation, the NBS could consider reselling in the fixing session on a daily basis the foreign exchange acquired from the exchange offices, net of accumulation motivated by long-term reserve accumulation goals. If the NBS were to phase in such resales gradually, it will need to weigh the costs and benefits of preannouncing the schedule for such resales (e.g., to resell 20 percent through October 31, 40 percent through December 31, etc.): on the one hand, publicly announcing such a schedule would unambiguously signal the NBS's withdrawal from discretionary foreign exchange intervention; on the other hand, as above, an overly abrupt exit may impart an unintended and undesirable shock. Balancing these concerns suggests announcement of a 
schedule at least several months long, while also standing ready to apply other instrumentsnotably adjustments in the repo rate and monetary policy transparency - to adjust to any consequent unintended and unanticipated shocks. A weaker approach-because it would send a more qualified signal of the authorities' commitment to the new monetary policy framework - could consist of the NBS starting immediately to resell say 20 percent, while committing to assess the appropriateness of increasing this share by 20 percentage points every two months, with the presumption that these increases would go ahead in the absence of serious market disturbances.

\section{Exchange Rate Trends}

16. Reforms noted above still allow official influence on exchange rate trends. In so far as the macroeconomic objectives of the authorities carry implications for the exchange rate - for example due to its implications for inflation - they may reflect those objectives in policy towards the repo rate. This approach reconciles the aim of allowing exchange rate volatility with that of securing overall macroeconomic objectives including in respect of the exchange rate.

\section{But the instinct to phase out discretionary foreign exchange intervention rather} than abandon it in one step should be resisted. This instinct may be strong given familiarity with this instrument and that to some extent, the repo is not yet tried and tested. But this approach is not advised - even for only some interim period - because it may undermine the effectiveness of the repo. For example in the case of trend excess capital inflows putting upward pressure on the currency, discretionary intervention could stem the appreciation and create domestic liquidity. But if this occurred, this would displace the repo as the central monetary policy instrument. Instead of discretionary intervention in such a case, a fiscal policy response would be best. And if that is not available, then the repo rate could be lowered achieving the same effect as discretionary intervention without clouding market confidence in the authorities' commitment to the new monetary and exchange rate regime. To the extent that instincts to persevere with discretionary intervention even for interim periods reflect doubts about the effectiveness of repo operations, those doubts should be addressed directly through appropriate reforms of repo operations, as discussed below.

\section{Repo Operations}

18. Repo operations can be strengthened. The NBS is currently conducting repos with two different maturities (two weeks and two months). The auction type used for both maturities is a variable interest rate tender (U.S. style). Until mid-May 2006, the tender announcement comprised a maximum bid rate. Since then, the tender announcement consists solely of the offered quantity. These arrangements have several drawbacks: 
- By simultaneously conducting two-week and two-month repos, while controlling interest rates for both operations, the NBS dilutes the signaling function of the two-week repo rate (Figure 1).

- Despite the recently increased role of repos in the conduct of monetary policy, the two-week repo rate has assumed little, if any, prominence in the NBS publication strategy, leaving market participants unclear about the monetary framework.

- The recent abolition of the maximum bid rate has undermined the signaling function of the two-week repo rate. ${ }^{19}$ In fact, market participants query if the revision in the auction mechanism was intended to yield a decline in the policy rate.

Figure 1: Repo Rates and Belibor

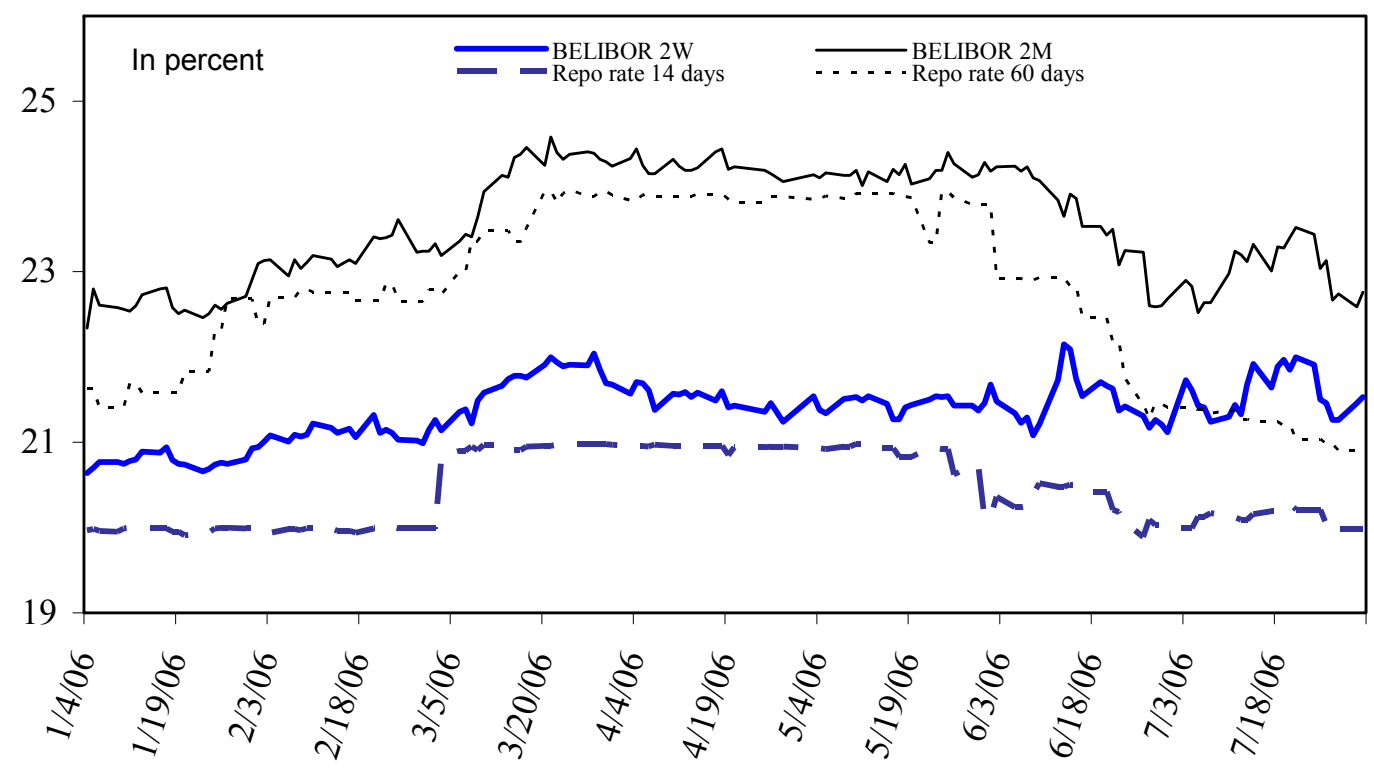

Source: NBS

19. To establish the two-week repo rate as the key policy rate, the role of two-month repos should deemphasized. By abandoning two-month repos operations, the NBS would establish the two-week repo rate as the sole monetary policy rate, thereby facilitating the transmission from the two-week repo rate to interbank rates. However, should the NBS wish

\footnotetext{
${ }^{19}$ Since the abolishment of the maximum bid rate, the two-week repo rate declined by almost 100 basis points. This decline was not accompanied by a public statement by the NBS on its policy intentions.
} 
to maintain two-month repos, the auction method for two-month repos would necessarily need to be revised: tenders should be variable rate tenders with pre-announced volume, with the NBS acting as a rate taker. ${ }^{20}$ Moreover, the volume of two-month repos should be reduced to a minor share of total repo operations. In this context, the NBS should communicate that the 2-month repo rate, by design, does not reflect the monetary policy stance.

20. In respect to the auction method for two-week repos, fixed rate tenders may be preferable at this juncture. While fixed rate and variable rate tenders should both be included as options in the operational framework, a fixed rate tender may be preferable during the transition to the revised monetary operations framework, as it could provide the least ambiguous policy signal and be easily supported by a communication strategy. Even if a variable rate tender works well and leads to only small fluctuations in the actual repo rate, such fluctuations may still cause confusion in the markets about policy intentions. Given the need to signal unambiguously commitment to the new regime and establish the central role of the 2-week repo rate within it, at this time these signaling considerations likely outweigh those tending to favor variable rate tenders. ${ }^{21}$

\section{The NBS may need to complement fixed interest rate tenders with a strategy for guiding market participants with respect to the envisaged liquidity withdrawal. In the} absence of such a strategy, a possible excess or shortfall of aggregate bids compared to the NBS liquidity forecast, at least if large, may induce unwarranted tensions in the interbank market, particularly given the prevailing segmentation of this market. Such guidance could be achieved through the regular publication by the NBS of its short-term (14 day) and medium-term (2 months) liquidity forecast. However, should the NBS not yet consider its liquidity forecast as sufficiently reliable or should market participants doubt the reliability of these forecasts, the NBS may wish to publish in the tender announcement the quantities that it intends to withdraw.

\footnotetext{
${ }^{20}$ With the NBS using repo rates for anchoring the formation of interbank interest rates at two different points on the yield curve, the latter does not necessarily reflect market expectations about future inflation and future interest rate conditions. Consequently, giving up this practice would provide valuable additional information for monetary policy.

${ }^{21}$ At this juncture, the unambiguous signaling of fixed rate tenders may outweigh the benefits of variable interest rate tenders that primarily consist of (i) fostering market development by creating incentives for banks to improve their liquidity projections and portfolio management; and (ii) providing information to the central bank about the banks' interest rate expectations liquidity needs. A transition from fixed rate to variable rate tenders may be warranted in the event of overbidding or underbidding, possibly resulting from expectations of interest rate adjustments.
} 
22. Should the NBS wish to continue with variable interest rate tenders, a return to the recently abolished practice of announcing maximum bid rates would be warranted. The significantly increased volatility of the highest accepted rate as well as the average weighted repo rate since end-May has given rise to doubts among market participants about monetary policy intentions. Therefore, the current practice is not consistent with the objective of strengthening the signaling function of the two-week repo rate.

23. The transition to a flexible exchange rate regime could at some future stage lead to need for liquidity providing repos. While the NBS is prepared for such transactions with respect to its legal framework and operational procedures, the availability of eligible assets on the side of the banks deserves further considerations. The stock of T-bills held by the banks fell sharply following the increase in the repo rate at end-2005 to the negligible amount of SRD 120 million at end-June. While T-bills could be complemented with FFCD bonds held by banks, this does not constitute a long-term solution owing to the transitory nature of these bonds. The NBS may, therefore, wish to discuss with the banks the scope for using bills of exchange as collateral, provided sufficient asset quality is secured. While foreign exchange swaps could also be considered, caution is warranted as this may give rise to the misinterpretation that the NBS is targeting a specific future exchange rate level.

\section{The 2-week repo rate should assume a prominent role in the NBS public} relations strategy. This implies that press statements after each Monetary Council meeting should explain the reasons for adjusting the two week repo rate or for leaving it unchanged. This explanation would have to comprise discussions of risks to the inflation objective as well as factors affecting the transmission channels from the repo rate to inflation.

25. The schedule of Monetary Council meetings could be reconsidered. To avoid problems of severe over- or under-bidding owing to market speculation about imminent repo rate changes, the NBS may wish to consider aligning the schedule of Monetary Council meetings with the reserve maintenance period.

\section{Interest Rate Corridor}

26. At present, there is no economically meaningful interest rate corridor. In 2005 , the NBS automatically linked the interest rates of its lending facilities to the weighted monthly average interest rates of repos of all maturities and also increased the interest rate on its deposit facility to 6 percent. While steps in the right direction, these measures left the Belgrade Overnight Index Average (Beonia) effectively delinked from the two-week repo rate, diminishing its role in money markets. During the period May-July 2006 the Beonia has fluctuated between 7.3 percent and 23.8 percent, with the average rate amounting to $13 \frac{1}{2}$ percent (Figure 2). Within this range, changes in the Beonia are determined by shortterm liquidity conditions (i.e. amounts deposited at the NBS deposit facility and the difference between banks' giro accounts and calculated required reserves). As a result, while changes in the repo rate affect the Beonia, the timing of the pass-through is uncertain and 
may occur with a significant delay. In the meantime, liquidity factors beyond the control of the NBS may move the Beonia in directions contrary to monetary policy objectives.

\section{Thus, the NBS could consider linking the deposit facility rate to the two-week}

repo rate and narrowing the spread between these two rates. In determining the appropriate spread, the NBS will have to weigh effectiveness and market development arguments. While the former favor a narrow spread, the latter may suggest that an overly narrow spread could induce banks to rely overwhelmingly on the deposit facility, thereby impeding the development of the nascent interbank market. To reflect market development considerations, the interest rate corridor could be narrowed in several steps. However, establishing an economically meaningful corridor to ensure a stronger pass-through from the two-week repo rate to the Beonia, requires a sizeable first step, which could consist of raising the deposit facility rate to a level above the current Beonia average of $13 \frac{1}{2} 2$ percent.

Figure 2: Beonia, Belibor, Repo Rates, and NBS Lending and Deposit Facilities

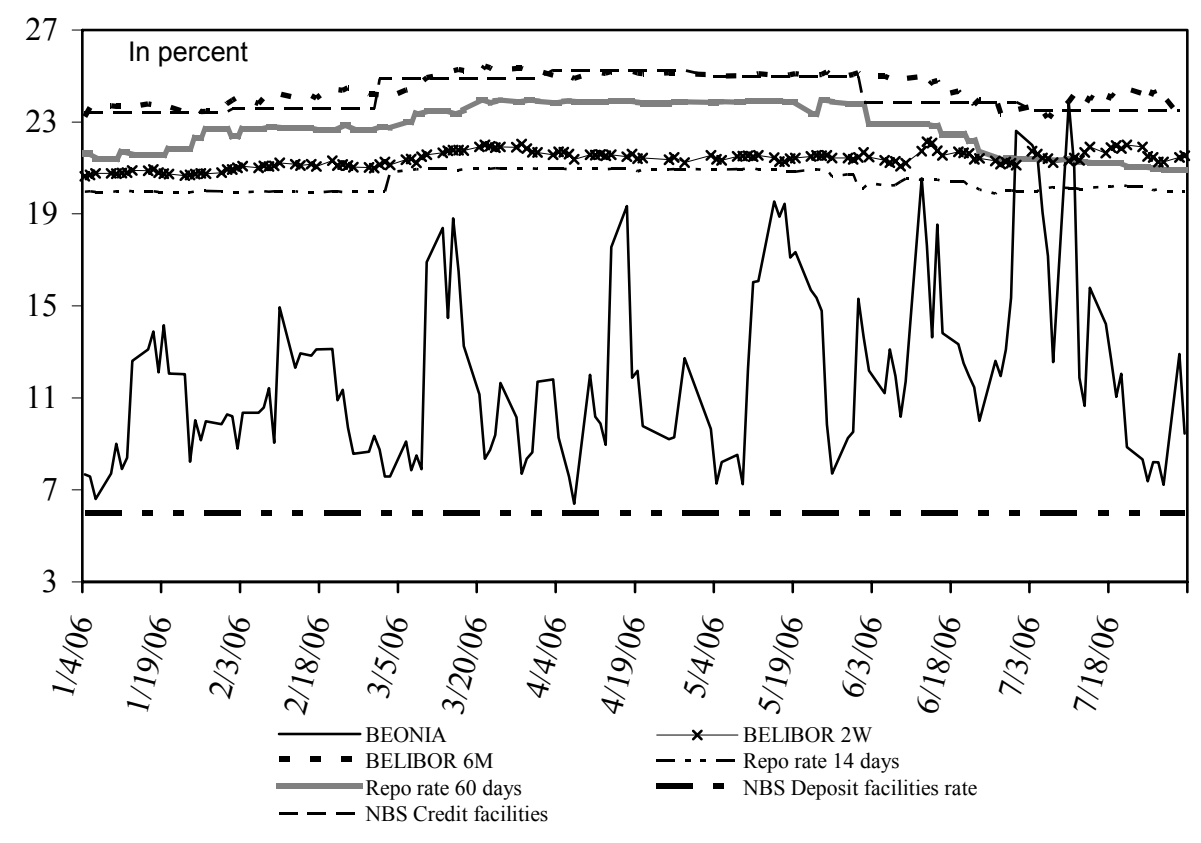

Source: NBS.

28. In addition, the interest rates on the NBS lending facilities should be linked to

the two-week repo rate. The current practice of linking these rates to the weighted monthly average of repo rates with all maturities is an impediment for the banks to use this instrument, as the actual interest rate that will be applied to the transaction is unknown in advance. Moreover, linking the NBS lending rates to the two-week repo rate would also strengthen the signaling function of the latter. 


\section{E. Transmission From the Repo Rate to the Exchange Rate}

\section{Recent experience suggests that the repo can already influence the exchange}

rate. In early 2006, and despite continued strong foreign exchange intervention, upward pressures on the dinar strengthened under the influence of the significant increase in the repo rate at the beginning of this year and a revision in March of regulations on banks' open fxposition. The latter excluded bank capital from the calculation of the open fx-position, effectively obliging banks to invest the counter value of their capital in dinar-denominated assets. The increase in the repo volume between end-2005 and end-April 2006 (SRD 17.6 billion) corresponds to 31.3 percent of commercial banks' net foreign borrowing during this period. With respect to the seven foreign banks that are the most active in the repo market (accounting for 88.9 percent of the total increase in the repo volume), this share amounts to 36 percent.

30. But the transmission form the repo rate to the exchange rate, even at best, will not always be smooth. The transmission has so far largely relied on a small number of foreign banks. The repo market is dominated by six foreign banks. ${ }^{22}$ Given the small number of players, a swift and smooth response of capital flows to changes in the repo rates may be hampered by exposure limits of parent banks, which could become binding constraints for additional capital inflows, most notably under circumstances of rising uncertainty and pressure on the exchange rate. In a similar vein, with banks' foreign borrowing denominated in foreign currencies, the allowed open fx-position established a ceiling for individual banks' additional demand for repos in the event of a repo increase.

31. Looking forward, however, the basis for the transmission from the repo rate to the exchange rate is likely to broaden. The high level of financial euroization implies that portfolio adjustments by residents can be a key determinant of exchange rate changes. Given the high level of fx-denominated deposits, this may be a powerful channel for transmitting changes in the monetary stance to the exchange rate. This channel will gain importance to the extent that sustained progress in disinflation reduces the risk premium on dinar-deposits; and banks offer sufficiently attractive deposit rates on dinar-denominated instruments. Achieving the latter also depends on the scope for banks to expand the share of non-indexed dinardenominated loans in their loan portfolio.

\footnotetext{
${ }^{22}$ While Komercijalna Banka also accounts for a sizeable share of the repo market, it was so far lacking the relatively easy access to foreign borrowing. However, this is about to change owing to the recent acquisition of a controlling minority stake in this bank by the EBRD.
} 
32. But major policy or international shocks and the strength of medium- and longterm capital inflows will challenge monetary policy making. Investor sentiment towards the dinar is even more fragile than vis-à-vis euro-denominated claims on Serbia. Adjustments in the repo rate may, therefore, need to be large. These considerations underscore the need to stabilize the broader policy environment -including notably in respect of fiscal and structural policies - in order to support the effectiveness of the envisaged monetary and exchange rate reforms. It also strengthens the case for broadening and deepening money and financial market with a view to widen the interest rate channel of monetary policy. 


\section{INFLATION ${ }^{23}$}

\section{The National Bank of Serbia (NBS) has recently proposed policy shifts} anticipating eventual adoption of an inflation targeting regime. Amongst other things, this would require identifying reliable predictors of future inflation. The nominal exchange rate is one candidate. In this regard, understanding exchange rate pass-through is key. The new monetary regime will need to be designed with this behavior in mind, and drawing on the experience of other countries. This note considers the empirical evidence on exchange rate pass-through into core inflation ${ }^{24}$ and reviews the experience of several other emerging market economies in dealing with various aspects of transition to inflation targeting.

\section{A. Exchange Rate Pass-Through to Core Inflation}

\section{General Considerations}

\section{Several studies have attempted to estimate exchange rate pass-through in} Serbia. NBS (2004) employed a one-equation error-correction model and found a passthrough of around 0.32-0.35 in 1997-2004. Gorbanyov (2005) examined VAR and VECM models and found that the pass-through rates vary across model specifications and sample periods. In particular, pass-through into core prices was found to be between 0.7 and 0.9 within a year using 2001-04 data, but dropped to about 0.4 when 1997-2004 data was used. Petrovic and Mladenovic (2005) also report low pass-through estimates using both a singleequation autoregressive distributive lag (ADL) model and a VECM model—about 0.5 using monthly data for 2001:7-2005:9. However, interpretation of these results - and their variety - should take account of a number of limitations in the studies.

\section{Data limitations suggest that structural models for Serbia need to be used with}

care. The short data sets imply significant loss of degrees of freedom in large structural models and they compromise efforts to verify cointegration (Text Table 1). ${ }^{25}$ And despite the short time period, structural breaks are a significant further difficulty_including the hyperinflation and disinflation between 1999 and 2002 (Text Figure 1), and various changes in the exchange rate regime, including post February 2006 (Text Figure 2). Moreover, the

\footnotetext{
${ }^{23}$ Prepared by Tokhir Mirzoev, with contributions from Janko Guzijan.

${ }^{24}$ Core prices comprise about 52 percent of the retail price index and mostly exclude agricultural and regulated prices (see Appendix Table A.1.).

${ }^{25}$ For example, Gorbanyov (2005) finds strong evidence of cointegration between prices and exchange rates in their sample, whereas Petrović and Mladenović (2005) argue the opposite and suggest a cointegrating relationship between exchange rate, core prices, unit labor costs and their measure of output gap.
} 
quality of the statistical series — notably those included in unit labor cost data — may be low. $^{26}$

Text Table 1. Core Price Index and Exchange Rate, Number of Cointegrating Relations 1/

\begin{tabular}{|c|c|c|c|c|c|}
\hline $\begin{array}{l}\text { Data Trend: } \\
\text { Model: }\end{array}$ & $\begin{array}{c}\text { None } \\
\text { No Intercept } \\
\text { No Trend } \\
\end{array}$ & $\begin{array}{c}\text { None } \\
\text { Intercept } \\
\text { No Trend } \\
\end{array}$ & $\begin{array}{c}\text { Linear } \\
\text { Intercept } \\
\text { No Trend } \\
\end{array}$ & $\begin{array}{c}\text { Linear } \\
\text { Intercept } \\
\text { Trend } \\
\end{array}$ & $\begin{array}{c}\text { Quadratic } \\
\text { Intercept } \\
\text { Trend } \\
\end{array}$ \\
\hline & \multicolumn{5}{|c|}{$2000 \mathrm{~m} 1-2006 \mathrm{~m} 6$} \\
\hline Trace Test & 1 & 1 & 1 & 2 & 2 \\
\hline \multirow[t]{2}{*}{ Max. Eigenvalue Test } & 1 & 1 & 1 & 2 & 2 \\
\hline & \multicolumn{5}{|c|}{$2001 \mathrm{ml}-2006 \mathrm{~m} 6$} \\
\hline Trace Test & 1 & 1 & 1 & 1 & 2 \\
\hline \multirow[t]{2}{*}{ Max. Eigenvalue Test } & 1 & 1 & 1 & 1 & 2 \\
\hline & \multicolumn{5}{|c|}{$2002 \mathrm{ml}-2006 \mathrm{~m} 6$} \\
\hline Trace Test & 1 & 0 & 0 & 1 & 2 \\
\hline \multirow[t]{2}{*}{ Max. Eigenvalue Test } & 1 & 0 & 0 & 0 & 0 \\
\hline & \multicolumn{5}{|c|}{$2003 \mathrm{~m} 1-2006 \mathrm{~m} 6$} \\
\hline Trace Test & 1 & 2 & 2 & 0 & 0 \\
\hline \multirow[t]{2}{*}{ Max. Eigenvalue Test } & 1 & 2 & 2 & 0 & 0 \\
\hline & \multicolumn{5}{|c|}{$2001 \mathrm{~m} 7-2005 \mathrm{~m} 92 /$} \\
\hline Trace Test & 1 & 0 & 2 & 1 & 2 \\
\hline Max. Eigenvalue Test & 1 & 0 & 0 & 1 & 0 \\
\hline
\end{tabular}

$1 /$ Test results are based on Johansen's cointegration test and an assumed 5 percent critical level.

2/ Sample used in Petrović and Mladenović (2005).

Text Figure 1. Serbia: Nominal Exchange Rate and Retail Prices

Twelve-month growth $(\mathrm{m} / \mathrm{m}(-12))$, percent

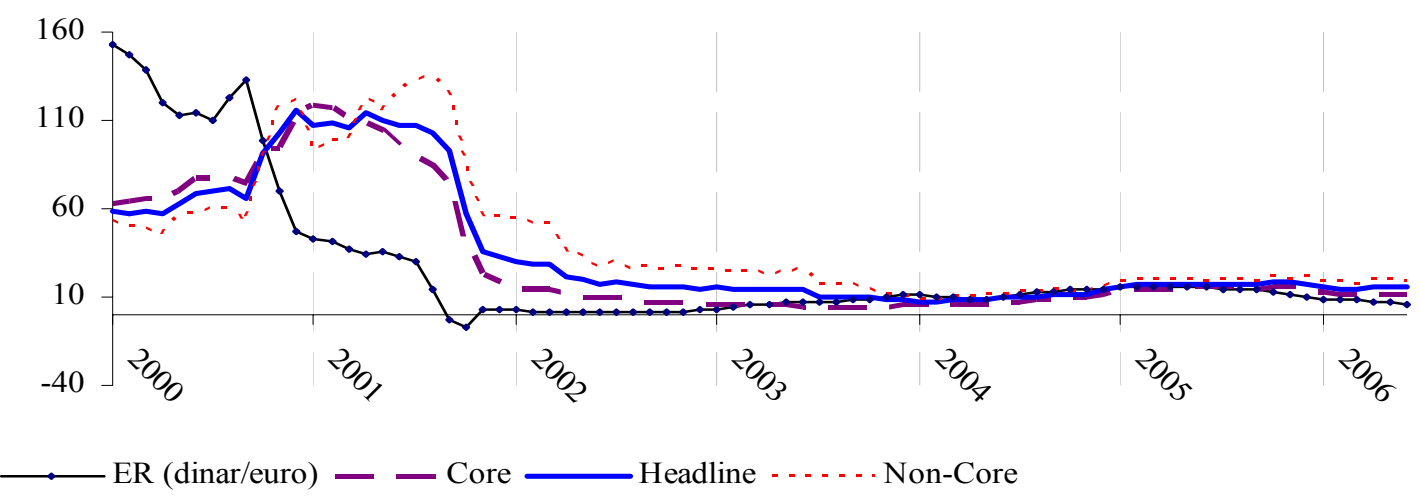

${ }^{26}$ Stanić (2005) and World Bank (2006) discuss shortcomings of the monthly wage and employment data. 
Text Figure 2. Serbia: Daily Exchange Rate

Dinar/Euro, Feb 01, 2005 - July 21, 2006

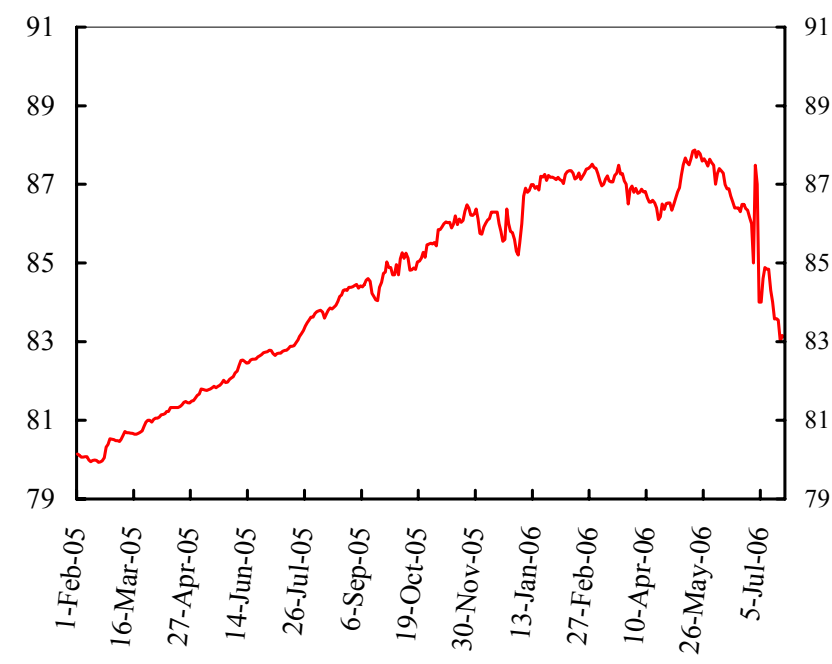

\section{Empirical Analysis}

\section{Analysis can most effectively start with visual inspection of the non-seasonally} adjusted data. ${ }^{27}$ Text Figure 3 plots core inflation and the nominal exchange rate at monthly, three-month, and twelve-month frequencies. Three-month and twelve-month growth series capture movements in the exchange rate that persist over their respective horizons. This is suggestive of asymmetric pass through:

- Pass-through seems to be larger for more persistent exchange rate shocks. Comovement of the exchange rate and core inflation is less evident in monthly changes - dominated by transitory and seasonal shocks, whereas three- and twelve-month trends exhibit stronger correlation.

- Pass-through may be slower when depreciation rates decline. This is suggested by the middle and lower charts of Figure 3 . The two episodes of persistent decline in depreciation rates are the pre-2003 exchange rate-based disinflation and the period of high capital inflows combined with greater exchange rate flexibility (from late 2005 onwards). In both episodes inflation responds with a lag to the deceleration of depreciation, perhaps reflecting sticky inflationary expectations. In contrast, between roughly March 2003 and September 2005 twelve-month depreciation and inflation were both on an

\footnotetext{
${ }^{27}$ The short length of the series weakens efficiency of seasonal adjustment.
} 
Text Figure 3. Serbia: Exchange Rate and Core Price Index

Monthly growth, percent (m/m(-1))

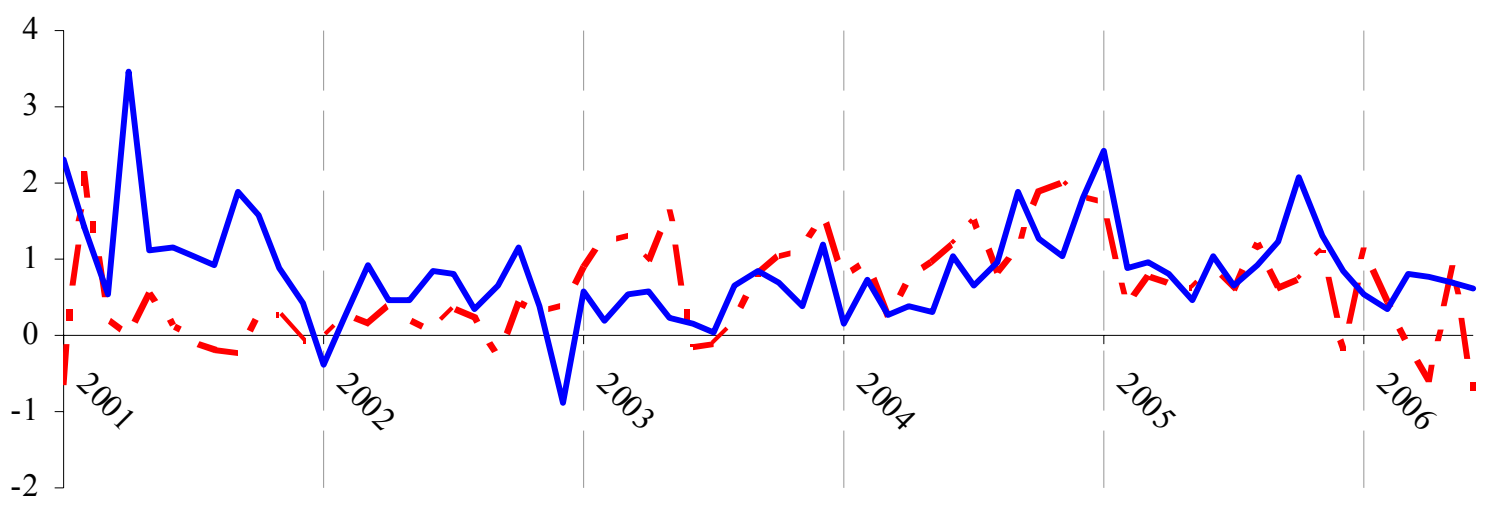

Three-month growth, percent $(\mathrm{m} / \mathrm{m}(-3))$

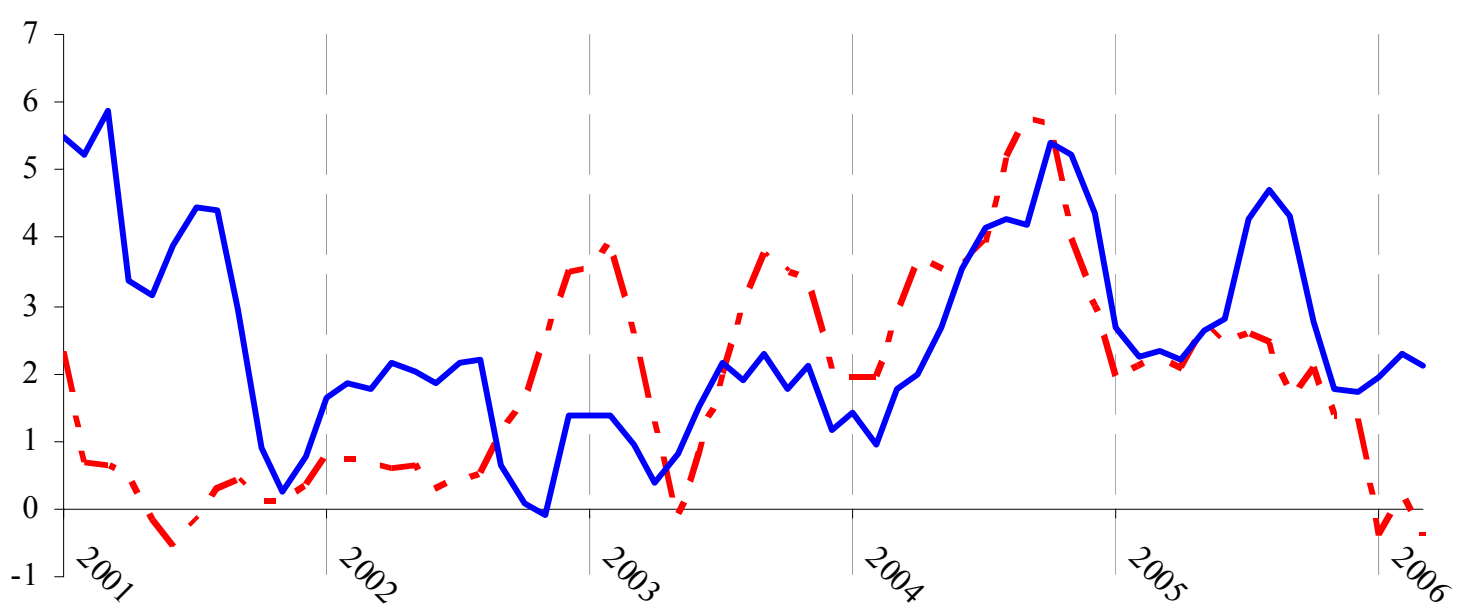

Twelve-month growth, percent $(\mathrm{m} / \mathrm{m}(-12))$

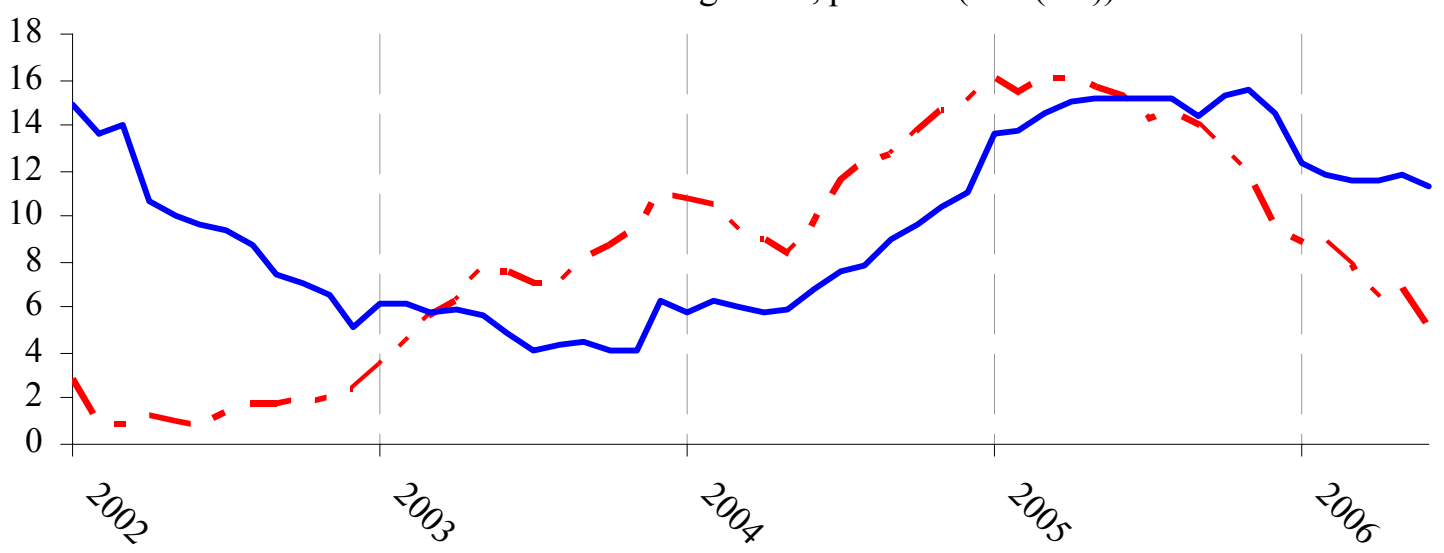

— - - ER (dinar/euro) C Core 
upward, although uneven, trend. The lead time in this period appears shorter and the correlation larger.

- However, there may be other explanations for the latter apparent asymmetry: prior to 2003, an equilibrating real exchange rate appreciation may have occurred following the hyperinflation and termination of economic sanctions; and from late 2005, a change in policy regime (accommodation of greater exchange rate volatility) and/or feed through to core inflation from rising international energy prices may account for the apparently altered relationship between the exchange rate and core inflation.

\section{In light of the various issues noted above, a single-equation autoregressive} distributed lag model was used to estimate exchange rate pass-through. Thus, the following equation was estimated:

$$
\pi_{t}=c+\rho \pi_{t-1}+\alpha s_{t}+u_{t}
$$

where $\pi_{t}$ is core inflation and $s_{t}$ is nominal exchange rate depreciation. Furthermore, to explore possible asymmetries, two samples were considered:

- 2003:3 through 2006:5 - full post-hyperinflation sample; and

- 2003:3 through 2005:9 - the period between the two main structural breaks which also corresponds to a rising trend in depreciation.

Comparison of the parameter estimates from the two data sets allows some insight into the possible different pass through behavior when exchange rate depreciation rates are declining. And insight into the possible dependence of pass through on the persistence of exchange rate shocks is obtained by comparing parameter estimates obtained from monthly series with those based on the three-month series. The results are reported in Text Table 2.

6. The findings suggest high pass-through and possible asymmetries. Using monthly growth rates, average exchange rate pass-through to the price level within one year was about 74 percent during the episode of a rising trend in depreciation and no apparent structural breaks, but dropped to just over 45 percent in the full sample. In principle, a lower estimate in the full sample can be attributed either to the structural break or the deceleration trend in depreciation, or both. It would be important to revisit this distinction once more data is available. However, a high noise-to-signal ratio in monthly series and the resulting poor model fit qualifies confidence in the results. Using three-month growth rates considerably 
strengthens both the model fit and pass-through coefficients which are above unity for both data periods. ${ }^{28}$ While the above unity estimates are not interpretable as conventional passthrough coefficients, ${ }^{29}$ they are still useful and suggest that changes in the depreciation trend, as opposed to short-lived changes, could be expected to pass-through almost fully into core inflation.

Text Table 2. Exchange Rate Pass-Through Estimates 1/

\begin{tabular}{|c|c|c|c|c|}
\hline & $\begin{array}{r}2003 \mathrm{~m} 3- \\
2006 \mathrm{~m} 6 \\
\end{array}$ & $\begin{array}{c}2003 \mathrm{~m} 3- \\
2005 \mathrm{~m} 9 \\
\end{array}$ & $\begin{array}{c}2003 \mathrm{~m} 3- \\
2006 \mathrm{~m} 6 \\
\end{array}$ & $\begin{array}{c}2003 \mathrm{~m} 3- \\
2005 \mathrm{~m} 9 \\
\end{array}$ \\
\hline & \multicolumn{2}{|c|}{ Monthly, m/m(-1) } & \multicolumn{2}{|c|}{ Three-month, m/m(-3) } \\
\hline Constant & $\begin{array}{l}0.30 \\
(0.14)\end{array}$ & $\begin{array}{l}0.15 \\
(0.17)\end{array}$ & $\begin{array}{l}0.18 \\
(0.24)\end{array}$ & $\begin{array}{l}-0.08 \\
(0.25)\end{array}$ \\
\hline Lag of Core Inflation & $\begin{array}{l}0.41 \\
0.14\end{array}$ & $\begin{array}{l}0.31 \\
(0.15)\end{array}$ & $\begin{array}{l}0.74 \\
0.08\end{array}$ & $\begin{array}{l}0.69 \\
(0.08)\end{array}$ \\
\hline Exchange Rate & $\begin{array}{l}0.24 \\
(0.11)\end{array}$ & $\begin{array}{l}0.44 \\
(0.15)\end{array}$ & $\begin{array}{l}0.19 \\
(0.07)\end{array}$ & $\begin{array}{l}0.30 \\
(0.09)\end{array}$ \\
\hline $\begin{array}{l}\text { Sample Size } \\
\text { Adjusted R-squared }\end{array}$ & $\begin{array}{c}40 \\
0.28\end{array}$ & $\begin{array}{c}31 \\
0.36\end{array}$ & $\begin{array}{c}40 \\
0.77\end{array}$ & $\begin{array}{c}31 \\
0.83\end{array}$ \\
\hline Cumulative pass-through into inflation, $\% 2 /$ & 40.3 & 63.8 & 75.6 & 96.2 \\
\hline $\begin{array}{l}\text { Pass-through rates into prices, } \% 3 / \\
1 \text { month } \\
2 \text { months } \\
6 \text { months } \\
12 \text { months } \\
24 \text { months } \\
\end{array}$ & $\begin{array}{l}24.0 \\
36.0 \\
45.0 \\
45.2 \\
45.2\end{array}$ & $\begin{array}{l}44.1 \\
63.7 \\
73.7 \\
73.8 \\
73.8 \\
\end{array}$ & $\begin{array}{c}19.4 \\
36.6 \\
80.6 \\
100.6 \\
104.9 \\
\end{array}$ & $\begin{array}{c}30.2 \\
57.1 \\
119.9 \\
140.4 \\
142.9 \\
\end{array}$ \\
\hline
\end{tabular}

1/ Standard errors are reported in parentheses

$2 /$ Sum of future expected changes in inflation following a one-time change in depreciation rate.

3 / Pass-through of a one time permanent change in the level of exchange rate into level of core price index.

\section{Possible asymmetries of pass-through have important implications for policy.}

First, policy would need to take account of these - anticipating faster price responses to depreciation than from exchange rate stabilization. Second, high noise-to-signal ratios in

${ }^{28}$ Using twelve-month changes (not reported here) strengthens this finding even further.

${ }^{29}$ Whereas monthly growth rates seem to be dominated by noise, three-month growth rates pick up more persistent changes. However, because of overlapping periods in the three-month data, three-month changes also tend to overstate the degree of persistence and, therefore, estimates of pass-through rates. 
monthly inflation warrants caution in policy makers' reaction to short-term fluctuations. Finally, slower pass-through in times of decelerating depreciation has implications for estimates of the costs of disinflation in terms of loss of competitiveness. Amongst other things, this highlights the importance of a sufficiently supportive fiscal policy in times of disinflation.

8. In sum, technical difficulties are reflected in the wide range of the pass through estimates, requiring care in their interpretation. On one hand, pass through coefficients obtained using three-month series are unrealistically high, due to persistence of the series. On the other hand, structural breaks (and/or asymmetry of pass-through with respect to low depreciation) casts doubt on the validity of low pass-through estimates in the full sample estimates. On balance, twelve-month pass-through of exchange rate shocks still seems high, over 70 percent, at least in times of rising depreciation.

\section{B. Inflation Targeting: Emerging Market Experience ${ }^{30}$}

\section{Experience in other emerging market countries which adopted inflation} targeting (IT) in the context of uncertainties in their empirical understanding of the determinents of inflation is instructive. Though most of these countries exhibited lower apparent degrees of exchange rate pass through, they generally had similar types of uncertainties on the behavior of inflation. So their experience-including on missing targets, disinflation prior to adopting IT, speed of transition towards IT, formulation of inflation targets, and steps towards developing an efficient forecasting framework - can help policy design in Serbia. The cases of Chile, Brazil, Czech Republic, Poland, Israel, and South Africa are highlighted below.

\section{Escape Clauses and Accountability}

10. Given the novelty of the regime in Serbia, there will be-at least in the initial stages of transition towards IT - some likelihood that pre-announced targets/objectives will be missed. Recognizing and explicitly integrating this into the monetary policy framework is important for building credibility. Central banks (CB) sometimes explicitly articulate the circumstances - typically outside of their control-under which such breaches would be tolerated (escape clause) and/or prescribe specific actions in the case of a target miss (explanation or accountability clauses).

\footnotetext{
${ }^{30}$ A more detailed discussion can be found in Mishkin and Schmidt-Hebbel (2002) and Schaechter et. al. (2000).
} 


\section{Of the six countries reviewed here, only the Czech Republic currently employs} an explicit escape clause. The clause is published on the central bank's website: ${ }^{31}$

"In the inflation targeting regime, the need for escape clauses derives from the occurrence of large shock changes in exogenous factors (particularly supply-side shocks) that are completely or largely outside the purview of central bank monetary policy. Attempts to keep inflation on target in these circumstances might cause undesirable volatility of output and employment. If such a shock deflects projected inflation from the target, the CNB does not respond to the primary impacts of the shock. It will apply an exemption (escape clause) from the obligation to hit the inflation target and accept the deviation of the inflation forecast from the target caused in this way. There are a whole range of shocks which can create room for applying such escape clauses. They include, for example, major deviations in world prices of energy raw materials or major deviations in agricultural producer prices. A specific type of exogenous shock is administrative measures that have strong price impacts, in particular major changes in the structure or rates of indirect taxes and major changes in the segment of regulated prices."

12. South Africa has had an escape clause in the past. It cited unpredictable events that could affect the inflation rate-e.g. significant changes in terms of trade, natural disasters, and interruption of external capital flows - as the circumstances under which the central bank could not be expected to reach the target. In November 2003 the escape clause was replaced with an explanation clause which required the Reserve Bank to explain reasons for deviations from the target and indicate by when the inflation rate was expected to return within the target range (see Merwe (2000)).

\section{Explanation clauses are in place in Israel and Brazil as well as in some mature} inflation targeters (e.g., Canada, Switzerland, and New Zealand). In Israel the CB is required to offer a public explanation in cases of deviations from the target of more than 1 percent. In Brazil, the CB must issue an open letter to the Ministry of Finance explaining reasons for the target breach and measures taken and the time required to bring inflation back on track. ${ }^{32}$ Poland and Chile do not employ either of the clauses.

\footnotetext{
${ }^{31}$ See http://www.cnb.cz/en/monetary policy/inflation_targeting.html\#c3

${ }^{32}$ Open letters for target misses in 2002-04 are available at http://www.bcb.gov.br/?INFLATION .
} 


\section{Is Achieving Low Inflation Essential Before Transition Towards Inflation Targeting?}

14. The argument for reducing inflation first is that some period of low inflation could help establish the central bank's track record, thus increasing its credibility. Disinflation might also be important to test the potency of the policy instrument before a regime switch. Nevertheless, the experience of the six countries suggests that this may not be necessary. For example, Chile, Israel and Poland have started their transition with double digit inflation rates (see Text Table 3).

Text Table 3. Inflation Prior to the Transition to Full-Fledged Inflation Targeting 1/

\begin{tabular}{lcccccc} 
Country & $\mathrm{t}$ & $\mathrm{t}$ Less 4 Years & $\mathrm{t}$ Less 3 Years & $\mathrm{t}$ Less 2 Years & $\mathrm{t}$ Less 1 Year & Inflation at t \\
\hline Brazil & 1999 & 66 & 15.8 & 6.9 & 3.2 & 4.9 \\
Chile & 1990 & 20.6 & 19.9 & 14.7 & 17 & 26 \\
Czech Republic & 1997 & $\ldots$ & 10.1 & 9.1 & 8.8 & 8.4 \\
Israel & 1991 & 19.8 & 16.3 & 20.2 & 17.2 & 19 \\
Poland & 1998 & 33.3 & 26.8 & 20.2 & 15.9 & 11.7 \\
South Africa & 1999 & 8.6 & 7.4 & 8.6 & 6.9 & 5.2 \\
\hline
\end{tabular}

Source: Schaechter et. al. (2000)

$1 / t$ is time of the start of the transition to full-fledged inflation targeting framework.

\section{How fast have countries moved towards a formal IT regime?}

15. The speed of transition has varied widely. Except for South Africa, all countries reviewed here employed a crawling peg before moving to IT (South Africa was targeting broad money growth and inflation and had a flexible exchange rate regime). Brazil and Czech Republic switched to formal inflation targeting immediately. Other countries moved more gradually, from 9 years in Chile to 3 months in Poland (see Text Table 4). In general, the speed of transition should depend on the degree of confidence by the CB in its ability to effectively control inflation.

Text Table 4. Transition to Inflation Targeting

\begin{tabular}{lcc}
\hline & $\begin{array}{c}\text { Beginning of Transition to } \\
\text { Inflation Targeting }\end{array}$ & $\begin{array}{c}\text { Adoption of Full-Fledged } \\
\text { Inflation Targeting }\end{array}$ \\
\hline Brazil & Jun-99 & Jun-99 \\
Chile & Sep-90 & Sep-99 \\
Czech Republic & Dec-97 & Dec-97 \\
Israel & Dec-91 & Jun-97 \\
Poland & Oct-98 & Mar-99 \\
South Africa & Aug-99 & Feb-00 \\
\hline
\end{tabular}

Source: Schaechter et. al. (2000) 


\section{On Specification of Targets}

16. Central Banks adopting IT are faced with three closely related decisions:

- Whether to target a point or a range.

- Appropriate horizon of the target.

- Price index to be targeted.

17. The key trade-off with respect to all three decisions is the ease of communication of policy to the public on one hand and the ability to deliver on the other. In particular, it is generally easier to communicate an annual point target for a recognizable price index (such as CPI). From the perspective of implementation, however, the preference would be towards hitting a range, over a longer-term horizon, and for a price index over which the $\mathrm{CB}$ has a greater degree of control (such as core CPI).

18. The ability to target headline inflation depends on the importance of prices that are inherently volatile (e.g., fuel) or not market-determined. The six central banks considered here currently target headline inflation. The Czech National Bank had started with targeting net inflation, which excluded administered prices, but switched to targeting headline CPI in 2004. In part, such switch was justified by a relatively low share of administered (10 percent) and fuel (5-6 percent) prices in the CPI. In Poland, the share of administered prices is higher (25 percent), but still well below the level of Serbia, where 45 percent of the prices are regulated, either directly or indirectly.

19. All six central banks currently specify target ranges with a mid-point, rather than single point targets. The width of the ranges has varied over time. For example, Israel and Chile started with a width of 5 percent (range of 15-20 percent) which was gradually brought down to 2 and 1 percent respectively (range of 2-4 percent and 2.5-3.5 percent).

\section{Data Shortcomings and Forecasting ${ }^{33}$}

20. A reliable framework for forecasting inflation is crucial. Such a framework is key for the determination of appropriate targets as well as for enhancing central banks' understanding of the transmission mechanism, including lags with which variations in the policy instrument translate into changes in inflation. Forecasting is especially challenging for emerging market countries, prompting central banks to employ a wide variety of tools to

\footnotetext{
${ }^{33}$ See Schaechter et. al. (2000), chapter 5, for further details.
} 
forecast inflation and formulate reasonable targets. In practice, inflation forecasts are based on a combination of indicator variables and qualitative judgment, time series econometric models and structural quantitative economic models.

21. Use of inflation indicators is important when formal modeling is not feasible. An inflation indicator refers to observable data that have been previously shown to provide useful signals regarding future changes in inflation. Various inflation indicators could be monitored on a regular basis to form a judgmental view of possible future price developments, including aggregate demand and supply variables, monetary aggregates, interest rate and - as discussed above - the exchange rate, past inflation, alternative price measures, and expectations (obtained through surveys).

\section{When available data allow modeling, forecasting can be done through either} time series or structural models, or both. Time series models impose less economic structure but usually provide better short-term forecasts, as well as a consistency check for the larger structural models. They are easy to produce and allow for frequent assessment of economic conditions. For example, ARIMA models rely mostly on the information within the variable in question and produce forecasts based on internal dynamic properties of the series. Since most macroeconomic series are highly persistent, the forecasts obtained in this fashion are usually accurate at very short horizons, but deteriorate rapidly as the forecast period expands. ${ }^{34}$ Inclusion of other explanatory variables or more complicated relationships (such as VARs) requires a simultaneous forecast of all variables, with ambiguous net effects on accuracy. Nevertheless, these models are also very popular among central banks.

\section{Structural models used by central banks to forecast inflation have important} common elements. These include an open economy demand curve, a (New Keynesian) Phillips curve, an international asset market equilibrium condition (some version of uncovered interest parity with adjustment for risk premium) and a monetary policy reaction function. These elements have been used extensively in empirical work on central bank behavior, monetary policy rules, and sacrifice ratios.

24. Emerging economies have traditionally relied less on structural models. This reflects (i) their relatively short experience with inflation targeting that complicates the generation of reliable estimates based on structural models; and (ii) ongoing changes in structural relationships. Nevertheless, at present, Brazil, the Czech Republic, and Israel all work with three or four equation models along the lines of those used by industrial country

\footnotetext{
34 The Central Bank of New Zealand, for example, relies on such models to produce two quarters ahead forecasts and uses large scale models for longer-term forecasting.
} 
central banks. There are clear benefits to using structural models. Besides forecasting, they provide an essential framework which helps policy makers think through various policy transmission channels and frame policy discussions within a coherent summary of their understanding of the economy. 


\section{References}

Gorbanyov, Michael, 2005, "Inflation Determinants in Serbia," Serbia and Montenegro Selected Issues and Statistical Appendix, IMF Country Report, No. 05/232 (Washington: International Monetary Fund).

Merwe A., 2004, "Inflation Targeting in South Africa," Occasional Paper, No. 19 (South Africa: South African Reserve Bank).

Mishkin, Frederic and Klaus Schmidt-Hebbel, 2002, "A Decade of Inflation Targeting in the World: What Do We Know and What Do We Need To Know?" in Loyaza Norman and Raimundo Soto, eds. Inflation Targeting: Design, Performance, Challenges.

NBS, 2004, “What Influences Inflation Rate In Serbia?” Economic Review (Serbia: National Bank), pp. 29-39.

Petrović, Pavle and Zorica Mladenović, 2005, "Econometric Modeling of Inflation in Serbia,” (Belgrade: University of Belgrade, manuscript).

Schaechter, Andrea, Mark R. Stone and Mark Zelmer, 2000, “Adopting Inflation Targeting: Practical Issues for Emerging Market Economies," Occasional Paper, No. 202 (Washington: International Monetary Fund).

Stanić, K., 2005, "Registered Employment and Wages - Statistic Data and Trends 2000-05," in Quarterly Monitor, (Belgrade: Center for Advanced Economic Studies).

World Bank, 2006, “Serbia: Labor Market Assessment,” (Washington: World Bank). 
Appendix Table A.1. Serbia: Composition of the Non-Core Price Index, 2006

\begin{tabular}{|c|c|c|c|c|}
\hline & \multirow{2}{*}{$\begin{array}{l}\text { Weight in Retail } \\
\text { Price Index } \\
\text { (percent) }\end{array}$} & \multirow[t]{2}{*}{ Type of regulation } & \multicolumn{2}{|c|}{ Responsible Agencies } \\
\hline & & & Proposal of changes & Final approval \\
\hline Agricultural products & 3.25 & Not regulated & & \\
\hline Wheat and bread & 2.44 & Indirect, through market interventions & Ministry of Trade & Cabinet of Ministers \\
\hline Maize floor, type 500 & 0.51 & $\begin{array}{l}\text { (sales of reserves from the commodity } \\
\text { reserve fund) mostly in cases of }\end{array}$ & & \\
\hline Wheat flour bread, type i & 0.26 & disruptions to market supply (e.g. due to & & \\
\hline Wheat flour bread, type ii & 1.67 & inclement weather) & & \\
\hline Fresh milk & 1.06 & Not regulated & & \\
\hline Tobacco products & 3.19 & Through excise taxes & Ministries of Finance & Cabinet of Ministers \\
\hline $\begin{array}{l}\text { Medical and other health products } \\
\text { Analgetic }\end{array}$ & $\mathbf{2 . 2 9}_{0.09}$ & Fixed administratively & Ministries of Health, Trade & Cabinet of Ministers \\
\hline Antipyretic & 0.18 & & & \\
\hline Antirheumatic & 0.15 & & & \\
\hline Beviplex & 0.01 & & & \\
\hline Ologovit & 0.12 & & & \\
\hline Antibiotics & 0.55 & & & \\
\hline Bactrim & 0.16 & & & \\
\hline Penicilin & 0.06 & & & \\
\hline Cough syrup & 0.06 & & & \\
\hline Nose drops & 0.06 & & & \\
\hline Antihypertensive & 0.35 & & & \\
\hline Antihistaminic in & 0.06 & & & \\
\hline Kardiotonici & 0.04 & & & \\
\hline Anksiolitici & 0.34 & & & \\
\hline Vitamin c, 20 tablets & 0.04 & & & \\
\hline Hansaplast & 0.01 & & & \\
\hline Thermometer, personal & 0.01 & & & \\
\hline Firewood & 1.15 & Fixed administratively (only producer & Ministries of Energy, & Cabinet of Ministers \\
\hline Coal & 0.33 & price of coal is fixed) & Mining, Finance and Trade & \\
\hline Liquid heating fuels and gas & 0.82 & & & \\
\hline Electricity & 7.16 & Fixed administratively & $\begin{array}{l}\text { Ministries of Energy, } \\
\text { Mining, Finance and Trade }\end{array}$ & Cabinet of Ministers \\
\hline $\begin{array}{l}\text { Liquid fuel } \\
\text { Motor petrol, bmb 95, } 1\end{array}$ & $\begin{array}{ll}8.33 \\
& 1.97\end{array}$ & $\begin{array}{l}\text { Fixed administratively, but with automatic } \\
\text { periodic adjustment according to a fixed } \\
\text { formula (fixed by law). The formula can in }\end{array}$ & $\begin{array}{l}\text { Formula is automatically } \\
\text { applied if: i) the price has } \\
\text { not been updated for } 15 \text { days }\end{array}$ & $\begin{array}{l}\text { Ministries of Energy } \\
\text { and Mining, Finance } \\
\text { and Trade }\end{array}$ \\
\hline Motor petrol, mb 95, 1 & 2.68 & principle be by-passed and tax incentives & or more; or ii) if the dinar & \\
\hline Motor petrol, mb 98, 1 & 0.47 & $\begin{array}{l}\text { used instead. The latter has not happened } \\
\text { since April } 2005\end{array}$ & $\begin{array}{l}\text { price of crude oil (either due } \\
\text { to exchange rate or oil }\end{array}$ & \\
\hline Gas oil d2 & 2.25 & & $\begin{array}{l}\text { prices) has changed by more } \\
\text { than } 1.5 \text { percent since the }\end{array}$ & \\
\hline Euro diesel & 0.96 & & previous adjustment. & \\
\hline Housing, public-utilities services & 8.55 & & & \\
\hline Water for household & 3.23 & Fixed administratively & Local (municipal) & Ministries of Trade \\
\hline Wastewater & 0.39 & & governments & and Finance \\
\hline Taking out rubbish from flat & 1.26 & & & \\
\hline Central heating & 3.23 & & & \\
\hline Fee for keeping motor vehicles & 0.44 & & & \\
\hline Mandatory car insurance & 0.80 & Fixed administratively & $\begin{array}{l}\text { Society of Car Insurance } \\
\text { Companies }\end{array}$ & $\begin{array}{l}\text { Ministry of Capital } \\
\text { Investments }\end{array}$ \\
\hline Transport services & 3.18 & Fixed administratively & Local authorities (for buses) & Ministries of Capital \\
\hline Bus city transport & 1.38 & & + Ministry of capital & Investments, Trade \\
\hline Monthly ticket & 1.35 & & Investments (for railways) & and Finance \\
\hline Railway passenger transport & 0.32 & & & \\
\hline Air passenger transport, etc.. & 0.13 & & & \\
\hline $\begin{array}{l}\text { Post, Telegraph and Telephone services } \\
\text { Postal services }\end{array}$ & ${ }^{4.65}$ & $\begin{array}{l}\text { Fixed administratively, except for mobile } \\
\text { phone charges (weight } 0.0116 \text { ), which are } \\
\text { market determined }\end{array}$ & $\begin{array}{l}\text { Ministries of Capital } \\
\text { Investments, Trade and } \\
\text { Finance }\end{array}$ & Cabinet of Ministers \\
\hline Telephone and telegraph & 4.32 & & & \\
\hline Social welfare services & 1.56 & Fixed administratively but only for public & Local Authorities & Ministry of Finance \\
\hline Monthly kindergarten fee & 1.39 & facilities & & \\
\hline Monthly payments for high school and college students & 0.17 & & & \\
\hline TV subscription & 0.58 & $\begin{array}{l}\text { Fixed administratively: the } 2005 \text { Law } \\
\text { prescribes annual adjustments by the rate } \\
\text { of inflation plus five percentage points. }\end{array}$ & $\begin{array}{l}\text { RTS (Serbian Broadcasting } \\
\text { Company) }\end{array}$ & Cabinet of Ministers \\
\hline Total weight & 48.19 & & & \\
\hline
\end{tabular}

